\title{
Can Mountain Waves Contribute to Damaging Winds Far Away from the Lee Slope?
}

\author{
JEFFREY D. KELLEY \\ NOAA/National Weather Service, Hastings, Nebraska \\ DAVID M. SCHULTZ \\ Centre for Atmospheric Science, School of Earth and Environmental Sciences, University of \\ Manchester, Manchester, United Kingdom \\ RUSS S. SCHUMACHER \\ Department of Atmospheric Science, Colorado State University, Fort Collins, Colorado \\ DALE R. DURRAN \\ Department of Atmospheric Sciences, University of Washington, Seattle, Washington
}

(Manuscript received 4 January 2019, in final form 4 September 2019)

\begin{abstract}
On 25 December 2016, a 984-hPa cyclone departed Colorado and moved onto the northern plains, drawing a nearby Arctic front into the circulation and wrapping it cyclonically around the equatorward side of the cyclone. A $130-\mathrm{km}$-wide and $850-\mathrm{km}$-long swath of surface winds exceeding $25 \mathrm{~m} \mathrm{~s}^{-1}$ originated underneath the comma head of the lee cyclone and followed the track of the Arctic front from Colorado to Minnesota. These strong winds formed in association with a downslope windstorm and mountain wave over Colorado and Wyoming, producing an elevated jet of strong winds. Central to the distribution of winds in this case is the Arctic air mass, which both shielded the elevated winds from surface friction behind the front and facilitated the mixing of the elevated jet down to the surface just behind the Arctic front, due to steep lapse rates associated with cold-air advection. The intense circulation south of the cyclone center transported the Arctic front and the elevated jet away from the mountains and out across Great Plains. This case is compared to an otherwise similar cyclone that occurred on 28-29 February 2012 in which a downslope windstorm occurred, but no surface mesoscale wind maximum formed due to the absence of a well-defined Arctic front and postfrontal stable layer. Despite the superficial similarities of this surface wind maximum to a sting jet (e.g., origin in the midtroposphere within the comma head of the cyclone, descent evaporating the comma head, acceleration to the top of the boundary layer, and an existence separate from the cold conveyor belt), this swath of winds was not caused by a sting jet.
\end{abstract}

\section{Introduction}

All sectors of extratropical cyclones can be associated with nonconvective high winds (e.g., Parton et al. 2010; Knox et al. 2011). One of the phenomena responsible for high winds in cyclones is sting jets (e.g., Browning 2004; Clark et al. 2005; Schultz and Sienkiewicz 2013; Schultz and Browning 2017; Clark and Gray 2018), although other mesoscale phenomena producing high winds include mountain waves and downslope winds (e.g., Brinkmann

Corresponding author: Jeffrey D. Kelley, jeff.kelley@noaa.gov
1974; Lilly 1978; Durran 1986; Cotton et al. 1995) and mesoscale gravity waves (e.g., Uccellini and Koch 1987; Schneider 1990; Bosart et al. 1998). These high winds can potentially be damaging and life-threatening. The number of fatalities that result from nonconvective high winds is comparable to those associated with straight-line winds produced by deep moist convection, especially in more heavily forested regions (Ashley and Black 2008).

One example of a nonconvective windstorm occurred during the afternoon and evening of Christmas 2016 when a deep cyclone traveled from Colorado to South 

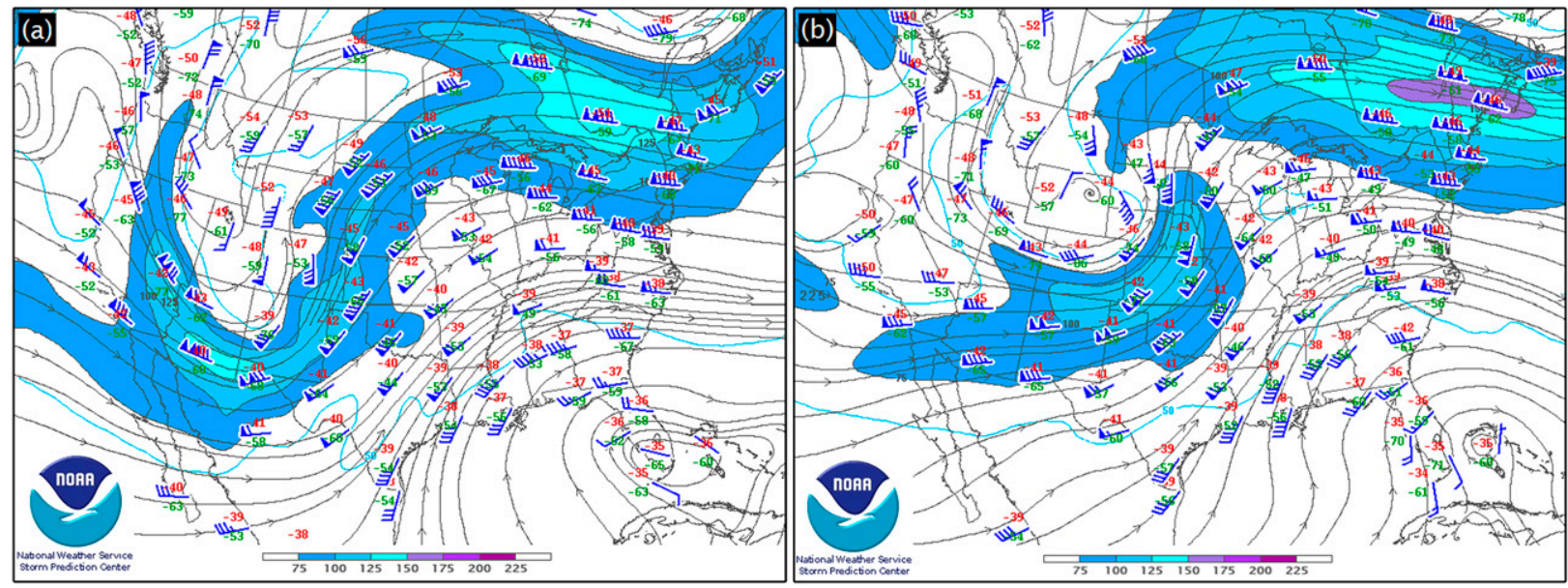

FIG. 1. Conventional station model plots at $300 \mathrm{hPa}$ for (a) 1200 UTC 25 Dec and (b) 0000 UTC 26 Dec 2016. North American Mesoscale $(\mathrm{NAM})$ model 6-h forecast of wind speed [ $\mathrm{kt}\left(1 \mathrm{kt} \approx 0.51 \mathrm{~m} \mathrm{~s}^{-1}\right)$; shaded according to scale] and streamlines, from $0600 \mathrm{UTC}$ in (a) and 1800 UTC in (b).

Dakota. A swath of high surface winds $130 \mathrm{~km}$ wide and $850 \mathrm{~km}$ long wrapped cyclonically around the southern periphery of the cyclone. Spotty damage occurred along most of this swath. Signs and trees were blown down, tree limbs and utility poles were snapped, irrigation pivots were flipped over, and outbuildings were damaged or destroyed. The damaged trees and utility poles resulted in scattered power outages. Damage was exacerbated over northeast South Dakota where more than $2.5 \mathrm{~cm}$ of ice accreted from freezing rain (NCEI 2016). Later, when the cyclone was in Minnesota, strong lower-tropospheric winds unusually extended all the way back to the lee slope of the Rockies. Importantly, the operational numerical weather prediction models (as well as some research-oriented models) were unable to correctly predict this surface wind maximum with much lead time, representing a critical forecast bust. The mesoscale models that did develop an area of high surface winds did not sustain the high winds eastward of central Nebraska, and the strongest winds were forecast too far north.

The goal of this study is to determine the origin of and physical processes responsible for two aspects of this case: the surface mesoscale wind maximum and the long extent of the lower-tropospheric winds. The goal is to better understand the causes of this event and why the forecast models might have missed it, with the goal to help forecasters anticipate similar events in the future, and thus to provide watches and warnings with longer lead times. The rest of this article is structured as follows. Section 2 presents a synoptic overview of the Christmas 2016 cyclone, followed by a description of the observed high surface winds in section 3 . The relationship between the strong winds and features in the satellite imagery are discussed in section 4. Isentropic maps and vertical cross sections are used in section 5 to diagnose the development and evolution of the mesoscale wind maximum at the surface. Section 6 compares this windstorm to the sting-jet conceptual model. Section 7 describes a case that occurred on 28-29 February 2012 in which a cyclone of similar strength occurred, but no surface mesoscale region of strong winds formed. Finally, section 8 concludes the article and provides recommendations for forecasters.

\section{Synoptic overview}

On 25 December 2016, an amplified upper-level pattern was over the United States, with a deep trough over the west and a ridge over the east (Fig. 1a). At 1200 UTC $(\mathrm{LT}=\mathrm{UTC}-6 \mathrm{~h})$, an upper-level jet streak was located at the southern tip of a negatively tilted trough. The sounding at Tucson, Arizona, measured 300-hPa winds of $67 \mathrm{~m} \mathrm{~s}^{-1}$. As the day progressed, the trough moved northeast with the jet streak rotating to the eastern side of the trough (Fig. 1b).

At the surface, this trough was associated with a surface cyclone which, during 23-25 December, moved onshore from the Pacific Ocean and then eastward through Nevada, Utah, and Colorado. At 1800 UTC 25 December, the occluded cyclone was over northeast Colorado with a central pressure of $986 \mathrm{hPa}$ (Fig. 2a). A west-east-oriented Arctic front became stationary across the northern Rockies and northern plains on 24 December. This front rotated cyclonically, and a small segment of this front was surging south into Colorado (Fig. 2a). The cold front with this cyclone moved into central Kansas and Oklahoma, while the western 

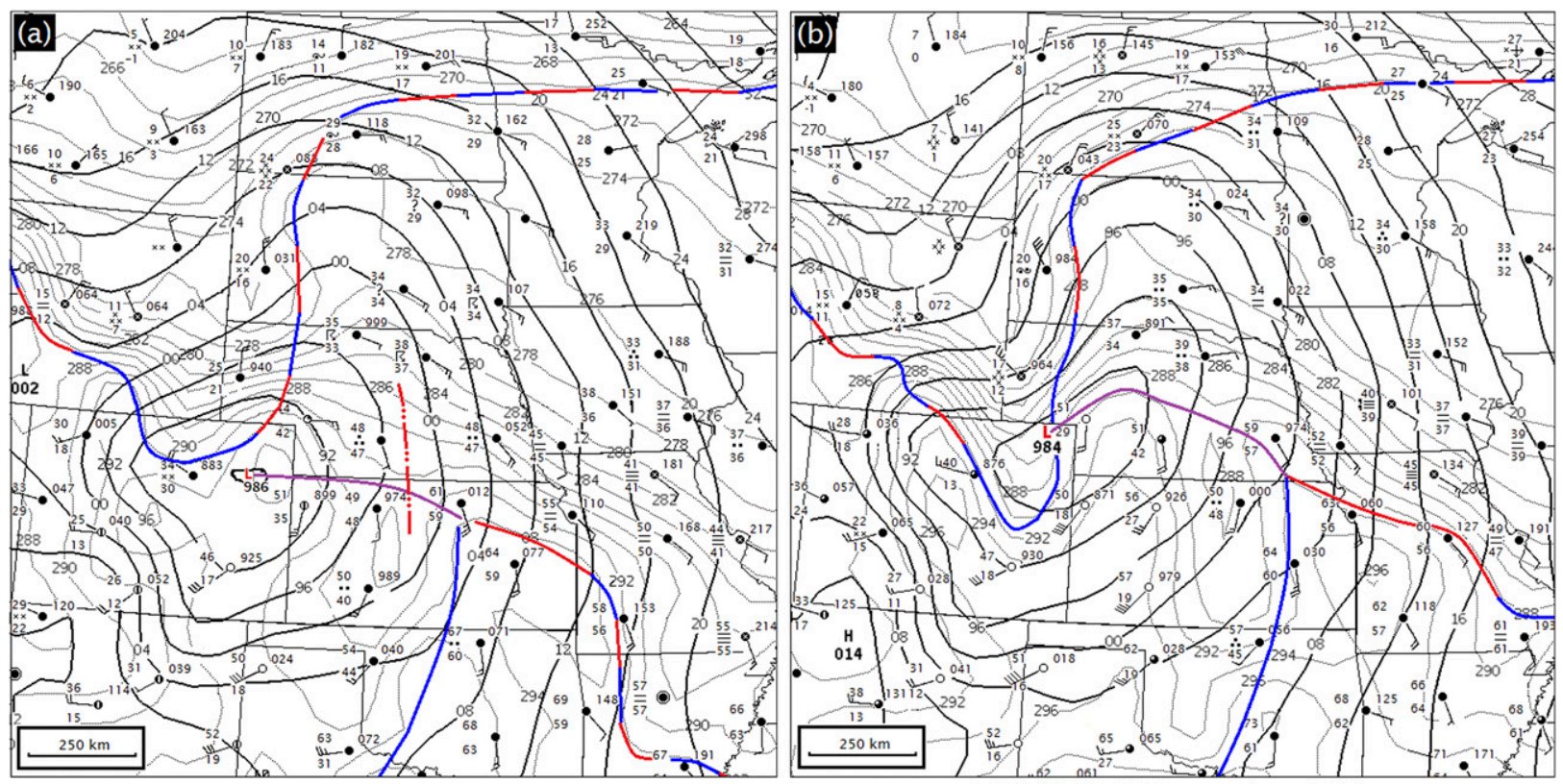

1800 UTC 25 December 2016

2100 UTC 25 December 2016
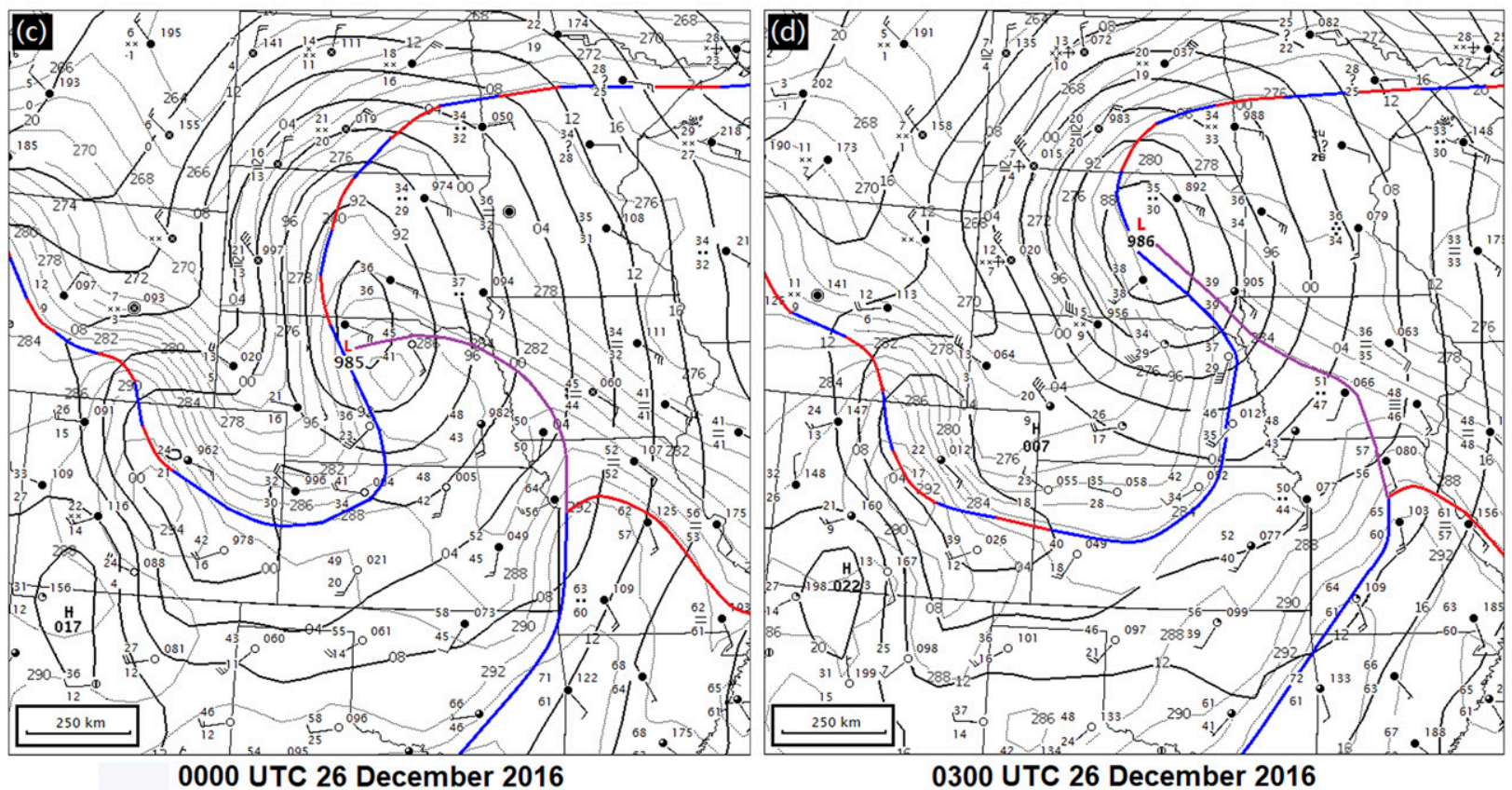

FIG. 2. Conventional station model plots $\left({ }^{\circ} \mathrm{F}\right.$ ) and subjective surface analyses at (a) 1800 UTC 25 Dec, (b) 2100 UTC 25 Dec, (c) 0000 UTC 26 Dec, and (d) 0300 UTC 26 Dec 2016. Fronts are represented by colored lines with the following notation: red: warm front, blue: cold front or Arctic front, purple: occluded front, and alternating red/blue: stationary front. The red line with double dots shows the location of a squall line. Isobars are drawn every $4 \mathrm{hPa}$ (solid, thick contours) and potential temperatures are drawn every $2 \mathrm{~K}$ (thin, dotted contours).

portion of the warm front was moving north through Kansas. A squall line was in progress from central Nebraska into northern Kansas, having formed in association with the cold front along the ColoradoKansas border between 1200 and 1400 UTC (around sunrise local time).
The small segment of the Arctic front continued surging south through eastern Colorado, accelerating to $15 \mathrm{~m} \mathrm{~s}^{-1}$ between 1800 and $2100 \mathrm{UTC}$, as the cyclone moved to the Colorado-Nebraska border (Fig. 2b). The occluded front moved into central Nebraska while the cold front moved farther east and the warm front 
advanced deeper into Missouri. The squall line dissipated from south to north between 1800 and 2000 UTC, with the last of the dissipating updrafts exiting Nebraska and entering South Dakota by 2000 UTC. This squall line produced damaging wind gusts and $11 \mathrm{EF} 0$ tornadoes between 1500 and 2100 UTC, from central Nebraska to central Oklahoma (NCEI 2016).

After 2100 UTC, the cyclone crossed western Nebraska and was located just south of Valentine, Nebraska, at 0000 UTC (Fig. 2c, see Fig. 3 for Valentine's location). The southward progress of the Arctic front slowed as it began to surge eastward, wrapping cyclonically around the southern periphery of the cyclone. Beginning at 2100 UTC, the average speed of the Arctic front increased to $27 \mathrm{~m} \mathrm{~s}^{-1}$. The occluded front had advanced through most of eastern Nebraska, while the cold front reached western Missouri (Fig. 2c). The northward progress of the warm front slowed.

By 0300 UTC, the cyclone was over central South Dakota (Fig. 2d). The Arctic front continued wrapping around the southern side of the cyclone and was close to merging with the occluded front. The triple point and cold front had moved deeper into Missouri.

The lowest central pressure while this low was over the Great Plains was $984 \mathrm{hPa}$. This was a deep cyclone for the region. Zishka and Smith (1980) examined a 27-yr climatology of cyclones over North America and found that the average minimum pressure for cyclones that form in the lee of the Rocky Mountains (from the Texas Panhandle to Alberta) was $996 \mathrm{hPa}$, noting that lee cyclones rarely reach the average lowest pressure of East Coast U.S. cyclones $(982 \mathrm{hPa})$.

\section{Observations of high surface winds}

High surface winds are defined by the National Weather Service (NWS) as sustained wind speeds of at least $18 \mathrm{~m} \mathrm{~s}^{-1}$ lasting for a minimum of $1 \mathrm{~h}$ or wind gusts of $25 \mathrm{~m} \mathrm{~s}^{-1}$ or more for any amount of time (NWS 2018). Wind gusts that equaled or exceeded $25 \mathrm{~m} \mathrm{~s}^{-1}$ for this case were classified into different groups, characterized by their causes, locations relative to the cyclone, times of occurrence, and wind directions (Fig. 3). Gusts plotted in red occurred in the clear, polar air behind the morning squall line. Gusts plotted in blue were associated with the cold conveyor belt (Carlson 1980; Schultz 2001). They were from the northwest and occurred later than the high winds associated with the mesoscale wind maximum. These red and blue gusts are not discussed further in this article. While impressive, those gusts were associated with features that are more familiar to forecasters. Gusts plotted in purple were associated with a downslope windstorm and will be discussed later.
Gusts plotted in black were associated with the mesoscale wind maximum and extended in a cyclonic arc from northeast Colorado to southwest Minnesota. These are the high winds that are the focus of this study.

This swath of wind gusts occurred over $12.5 \mathrm{~h}$ from 1930 UTC 25 December to 0800 UTC 26 December; the winds in this swath were primarily from the southwest and exhibited temporal continuity with the progression of the Arctic front. The axis of these high winds was approximately $275 \mathrm{~km}$ to the right of the cyclone track. The highest gust recorded was $35 \mathrm{~ms}^{-1}$ at Aurora, Nebraska (AUH; see Fig. 3 for location), at 0100 UTC, although the highest wind gust may have been missed at some locations. Most Automated Weather Observing System (AWOS) stations report every $20 \mathrm{~min}$ and only report the peak wind gust in the 10 min preceding an observation. The 5-min observations were obtained from selected AWOS sites in Nebraska, and it was from those data that the peak gust at Aurora was discovered.

The first detected high winds associated with this wind maximum occurred at Sterling, Colorado (STK), at 1930 UTC, shortly after the passage of the Arctic front (Figs. 2a,b). A tight gradient in wind speed existed between locations that experienced high winds and those that did not. For example, York, Nebraska (JYR), is only $32 \mathrm{~km}$ east of Aurora, but the peak wind gust there was only $20 \mathrm{~m} \mathrm{~s}^{-1}$ (Fig. 3). Similarly, the peak wind gust at Smith Center, Kansas (K82), was only $19 \mathrm{~m} \mathrm{~s}^{-1}$, and Smith Center is located just $43 \mathrm{~km}$ east of Phillipsburg, Kansas, where the peak wind gust was $31 \mathrm{~m} \mathrm{~s}^{-1}$. Winds abruptly increased almost immediately after frontal passage. For example, observations every $5 \mathrm{~min}$ from five AWOS stations owned by the Nebraska Department of Aeronautics showed rapid increases in wind speeds, with gusts exceeding $25 \mathrm{~m} \mathrm{~s}^{-1}$ within $10 \mathrm{~min}$ of frontal passage. But, the high winds lasted no more than $2 \mathrm{~h}$ at any single location. These rapid increases in wind speeds after frontal passage, and the short duration of the high winds, were typical along the entire path of this wind maximum.

The observations at Aurora illustrate the relationship between the passage of the Arctic front and the occurrence of the strong winds that was typical for many of the stations within the swath of strong winds (Fig. 4). In the $20 \mathrm{~min}$ prior to the passage of the Arctic front at Aurora, winds were from the south around $10 \mathrm{~m} \mathrm{~s}^{-1}$, with gusts around $15 \mathrm{~m} \mathrm{~s}^{-1}$ (Fig. 4). At 0025 UTC, passage of the front resulted in a wind shift to the southwest. Five minutes later, winds increased to $19 \mathrm{~m} \mathrm{~s}^{-1}$, gusting to $24 \mathrm{~m} \mathrm{~s}^{-1}$. Ten minutes after frontal passage, wind gusts had increased to $30 \mathrm{~m} \mathrm{~s}^{-1}$. Sustained winds remained between 20 and $25 \mathrm{~m} \mathrm{~s}^{-1}$ from 0030 to 0140 UTC. Gusts equaled or exceeded $30 \mathrm{~m} \mathrm{~s}^{-1}$ from 0045 to 


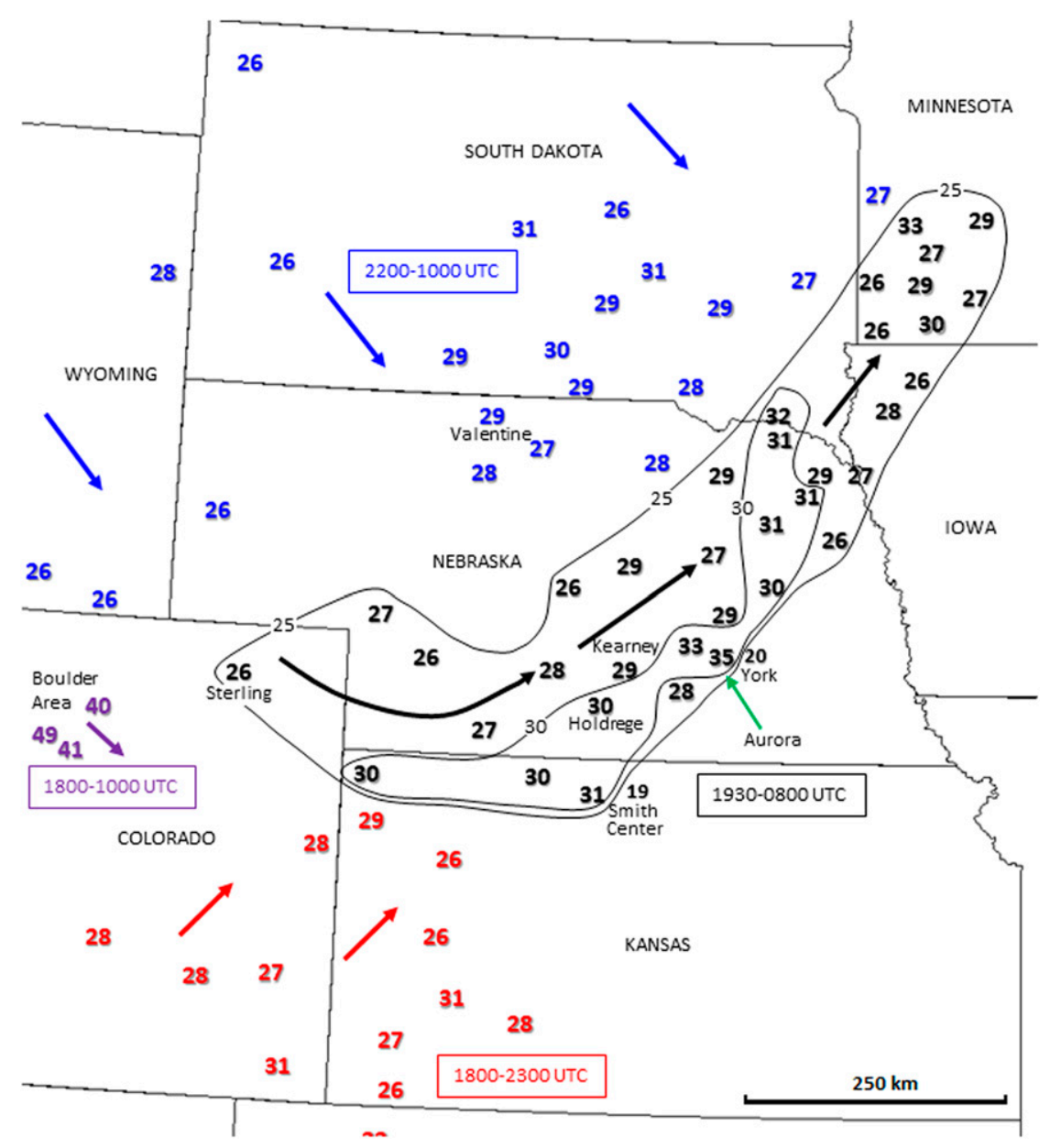

FIG. 3. Highest observed wind gusts of $25 \mathrm{~m} \mathrm{~s}^{-1}$ and greater. Peak gusts in black were associated with the mesoscale wind maximum and occurred from approximately 1930 UTC 25 Dec to 0800 UTC 26 Dec 2016. Contours associated with these gusts are plotted at 25 and $30 \mathrm{~m} \mathrm{~s}^{-1}$. Black arrows indicate the average wind direction associated with the gusts. The green arrow points to Aurora, Nebraska, where the peak wind gust of $35 \mathrm{~m} \mathrm{~s}^{-1}$ occurred. Peak wind gusts of $19 \mathrm{~m} \mathrm{~s}^{-1}$ at Smith Center, Kansas (K82), and $20 \mathrm{~m} \mathrm{~s}^{-1}$ at York, Nebraska (JYR), are extreme examples of the tight gradient in observed gusts. Peak gusts in blue were associated with the cold conveyor belt from 2200 UTC 25 Dec to 1000 UTC 26 Dec. Blue arrows indicate the average wind direction. Peak wind gusts in red were due to deep mixing in the polar air from 1800 UTC 25 Dec to 2300 UTC 25 Dec. Red arrows indicate the average wind direction. Peak wind gusts in purple are associated with a downslope windstorm, and the purple arrow indicates the average wind direction. The $49 \mathrm{~m} \mathrm{~s}^{-1}$ wind gust occurred at Gold Hill. The $41 \mathrm{~m} \mathrm{~s}^{-1}$ wind gust occurred at the Rocky Flats National Wildlife Refuge, and the peak gust of $40 \mathrm{~m} \mathrm{~s}^{-1}$ occurred at the National Center for Atmospheric Research in Boulder. Labeled locations not mentioned here are discussed in the text.

0130 UTC, with the peak wind gust of $35 \mathrm{~m} \mathrm{~s}^{-1}$ occurring at 0100 UTC. The last gust of at least $25 \mathrm{~m} \mathrm{~s}^{-1}$ occurred at $0140 \mathrm{UTC}, 1 \mathrm{~h}$ and $15 \mathrm{~min}$ from the time of frontal passage. Thus, the strongest winds occurred shortly after the passage of the Arctic front and lasted for less than $2 \mathrm{~h}$. These winds were stronger than those associated with the typical Arctic front passage over the Great Plains and were stronger than the postfrontal winds associated with this Arctic front before it encountered the cyclone (e.g., Fig. 2a). In this sense, forecaster experience indicates that the strength of these winds and their areal coverage were unusual for the Great Plains in this synoptic setting, a further reason for studying this unusual event.

\section{Relationship between high winds and features in satellite imagery}

Satellite images are useful for depicting the location of the high winds relative to the comma head of the cyclone 
(a)

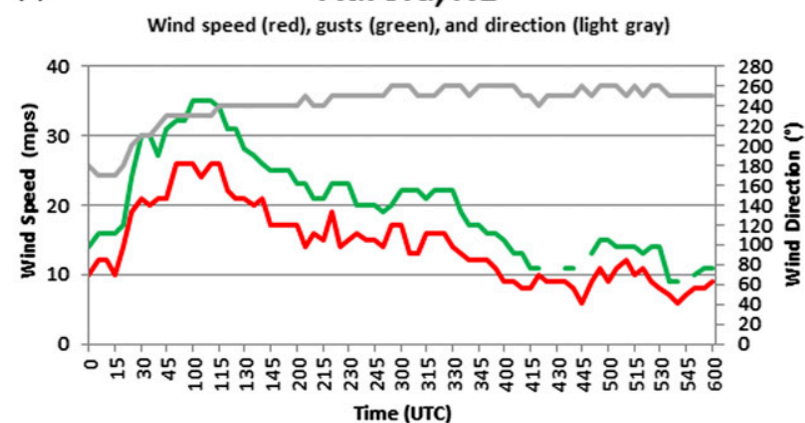

(b)

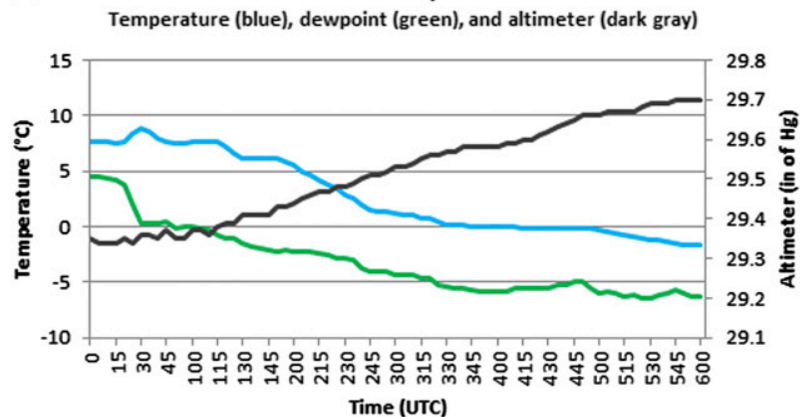

FIG. 4. The 5-min observations from the Aurora, Nebraska (AUH), Automated Weather Observing System from 0000 to 0600 UTC 26 Dec 2016. (a) Sustained wind speed $\left(\mathrm{m} \mathrm{s}^{-1}\right.$; red), gusts (green), and direction $\left({ }^{\circ}\right.$; light gray). (b) Temperature $\left({ }^{\circ} \mathrm{C}\right.$; blue), dewpoint $\left({ }^{\circ} \mathrm{C}\right.$; green), and altimeter (in. $\mathrm{Hg}$; dark gray).

and the Arctic air mass (Figs. 5 and 6). The progression of the cloud head from 0015 to 0315 UTC indicates that erosion and dissipation of midlevel clouds was extensive, even to the point that the tip of the comma head (also termed "cusp" by Carlson 1998, p. 236) was no longer identifiable (Figs. 5a-d). The brightness temperatures of the brighter white clouds were between $-20^{\circ}$ and $-29^{\circ} \mathrm{C}$, and routine airport observations (METARs) indicated the bases of these clouds were between 2700 and $3600 \mathrm{~m}$ AGL. These clouds were fairly extensive along the western Kansas-Nebraska border at 0015 UTC (Fig. 5a). However, by 0315 UTC, the clouds at the leading edge of the curled tip of the cloud head had completely dissipated over northeast Nebraska (Fig. 5d). The movement of the tip of the cloud head was northeast at $25 \mathrm{~m} \mathrm{~s}^{-1}$, very close to, but just slightly slower than, the speed of the Arctic front.

The colder air associated with the Arctic front is visible in a comma-shaped area to the north, east, and south of the comma head (cf. Figs. 2 and 5). The overlaid wind gusts further confirm that the high winds occurred behind the Arctic front. Earlier satellite imagery and METAR observations (not shown) indicate that the high winds began within the cloudy portion of the comma head. However, after 0100 UTC, the high winds were occurring under mostly clear skies (Figs. 5b-d). The dissipation of the clouds, and the warming of the cloud tops, suggests subsidence was occurring in the midtroposphere as air exited the comma head and descended into the dry slot from behind. At 0100 UTC (Fig. 6), water vapor imagery indicated that the dry slot had wrapped into South Dakota. A narrow, localized channel of meso- $\beta$-scale midtropospheric drying, and associated with active or previous subsidence adjoined the larger dry slot, and was collocated with the high winds at the surface. In combination with the erosion and dissipation of clouds, this imagery provides further confirmation that localized subsidence was occurring in the midtroposphere.

\section{Development and evolution of the mesoscale wind maximum}

Given these observations that suggest descent and the Arctic front may be linked to the strong winds at the surface, this section investigates the formation of the mesoscale wind maximum and its subsequent evolution through isentropic maps from the hourly Rapid Refresh (RAP) model initializations. The RAP model uses the Advanced Research version of the Weather Research and Forecasting (WRF) Model with 13-km grid spacing (Benjamin et al. 2016).

\section{a. 285-K isentropic maps and the evolution of the mesoscale surface wind maximum}

In this subsection, we present a series of maps on the 285-K isentropic surface (Fig. 7). The point of this series of maps is not to represent quantitatively the physical processes inside the cloud head along this single surface, but to present the structure of the atmosphere along a highly sloping surface that encompasses the bottom part of the cloud head $(750-850 \mathrm{hPa})$ to the unsaturated subcloud air and wind maximum $(750-950 \mathrm{hPa})$. Where the air is unsaturated, the flow will tend to lie along this surface more closely.

At 1900 UTC, a small wind maximum began to appear along the Nebraska-Wyoming border downstream of the Laramie Mountains in southeastern Wyoming (Fig. 7a). By 2100 UTC, the maximum wind speed increased and the area of the strong winds grew eastward and intensified, while still remaining anchored to the lee of the mountains (Fig. 7b). Air was descending along the isentropic surface from $725 \mathrm{hPa}$ over eastern Wyoming to the frontal zone below 


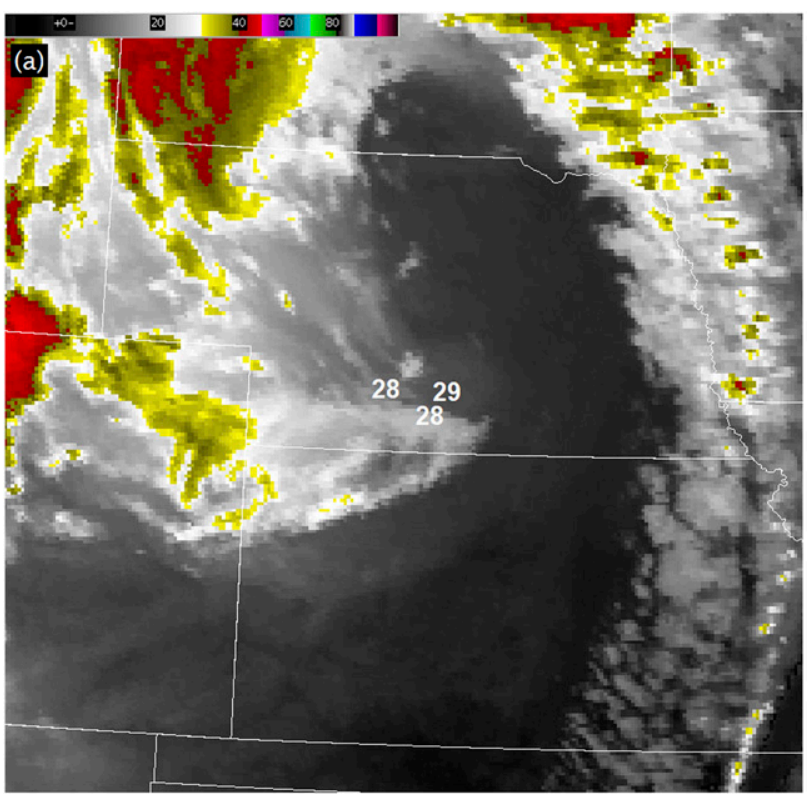

0015 UTC 26 December 2016

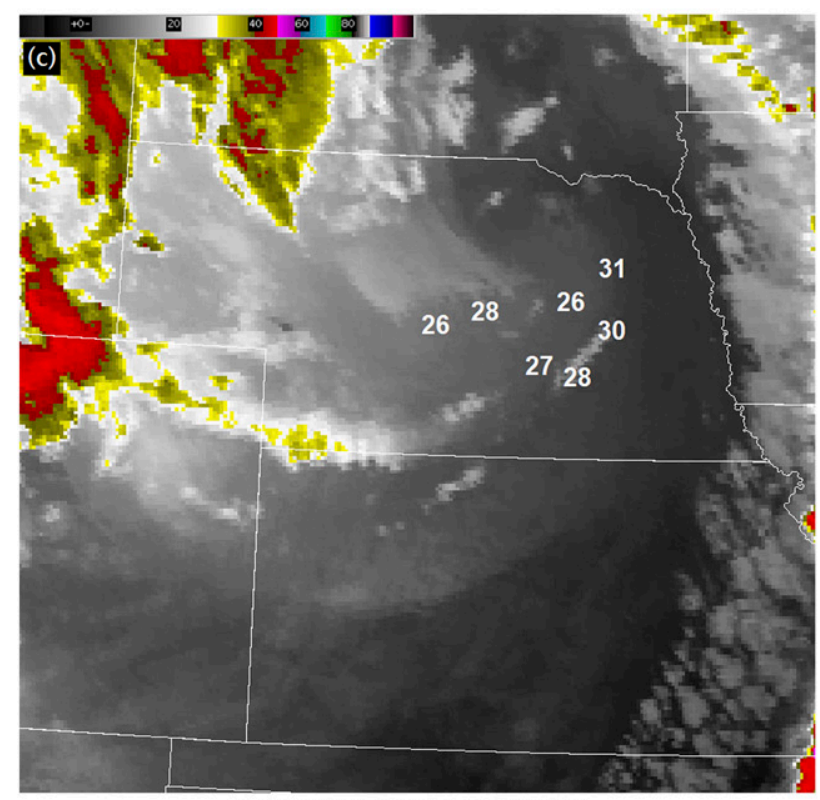

0200 UTC 26 December 2016

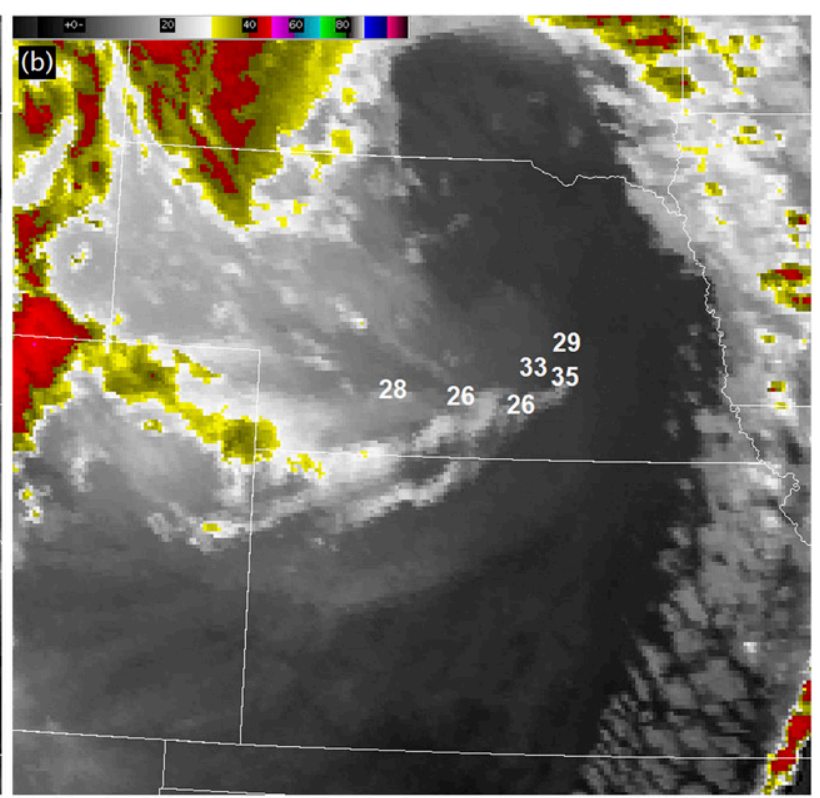

0100 UTC 26 December 2016

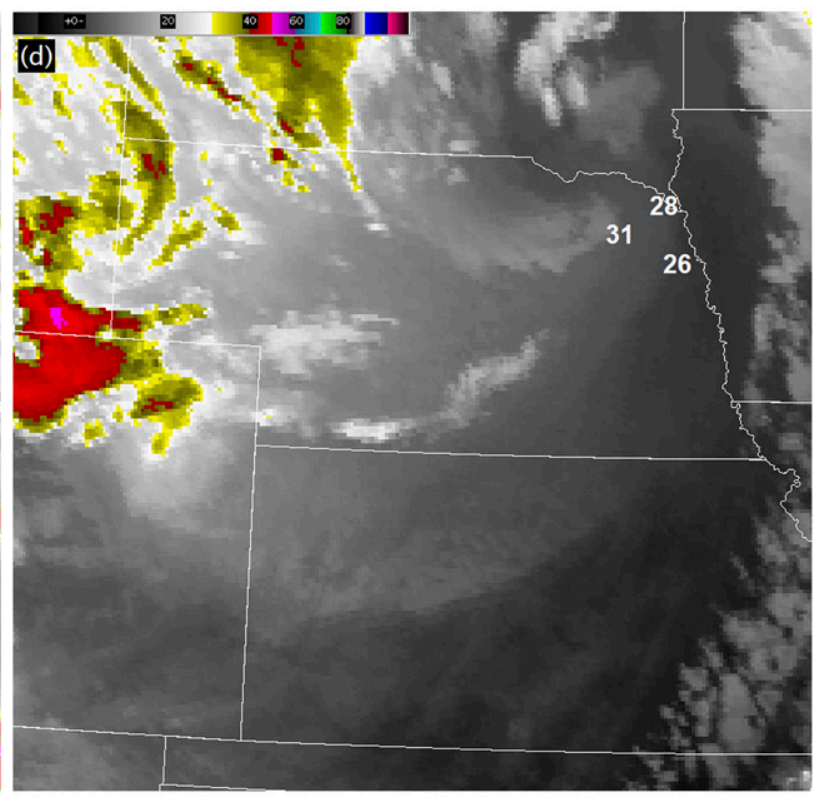

0315 UTC 26 December 2016

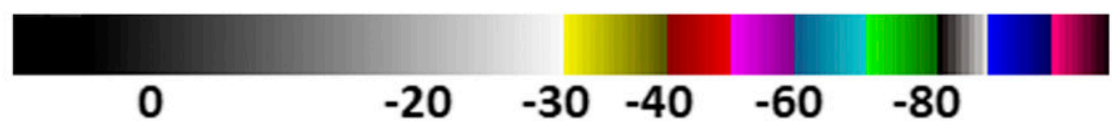

FIG. 5. GOES infrared satellite image at (a) 0015, (b) 0100, (c) 0200, and (d) 0315 UTC 26 Dec 2016. The color scale ( ${ }^{\circ} \mathrm{C}$ ) was modified at temperatures higher than $-30^{\circ} \mathrm{C}$ to accentuate the leading edge of the Arctic air and the low- to midtropospheric clouds. Highest wind gusts observed within the $30 \mathrm{~min}$ preceding each satellite image are annotated $\left(\mathrm{m} \mathrm{s}^{-1}\right)$. These gusts may not necessarily be the peak gusts that occurred at each location.

$850 \mathrm{hPa}$. Comparison with the surface analysis at 2100 UTC (Fig. 2b) indicates the leading edge of this wind maximum had reached the surface and had become collocated with the Arctic front.
Beginning at 2300 UTC, wind speeds within the wind maximum increased to more than $25 \mathrm{~m} \mathrm{~s}^{-1}$ from near $700 \mathrm{hPa}$ down to the surface position of the Arctic front (Fig. 7c). A small core of $30 \mathrm{~m} \mathrm{~s}^{-1}$ winds appeared 


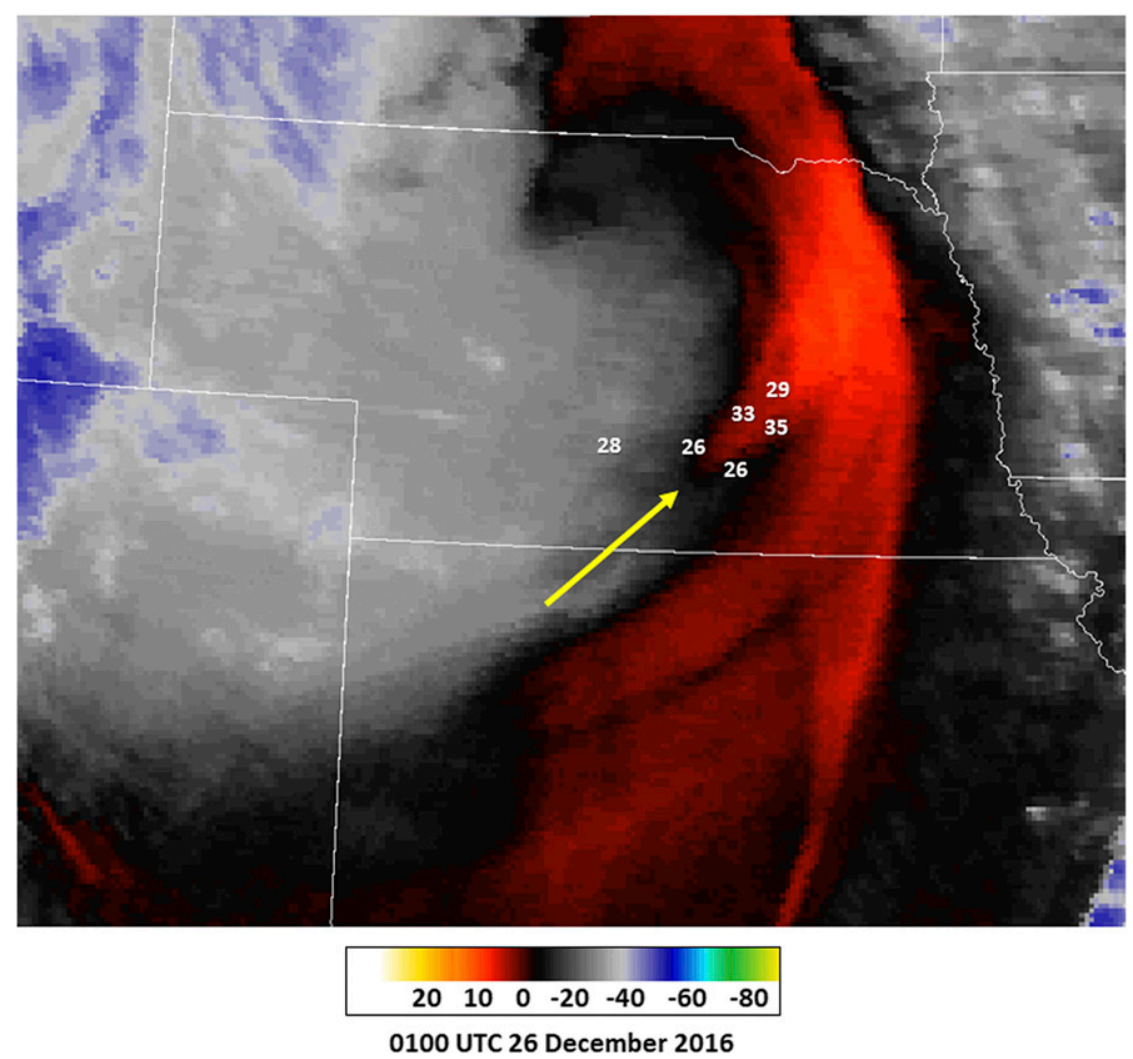

FIG. 6. GOES water vapor satellite image at 0100 UTC 26 Dec 2016 (color scale is in ${ }^{\circ} \mathrm{C}$ ). Highest wind gusts observed within the $30 \mathrm{~min}$ preceding this time are annotated $\left(\mathrm{m} \mathrm{s}^{-1}\right)$. These gusts may not necessarily be the peak gusts that occurred at each location. The yellow arrow indicates the channel of meso- $\beta$-scale subsidence.

immediately behind the Arctic front and was as low as $875 \mathrm{hPa}$ over southwest Nebraska. The tip of the cloud head was still present (indicated by the shaded relative humidity), but drying and erosion of cloud was apparent immediately upstream, in an area of continued descent. This drying becomes more pronounced from 0000 to 0100 UTC as the Arctic front and the leading edge of the wind maximum progressed eastward across southern Nebraska (Figs. 7d,e).

The relative humidity field shows a similar evolution to the features of relevance in the satellite imagery (cf. Figs. 7 and 5). By 0300 UTC, the tip of the cloud head had evaporated on this isentropic surface (Figs. 7d-f). An extensive area of winds exceeding $25 \mathrm{~m} \mathrm{~s}^{-1}$ was descending from the midtroposphere and wrapping cyclonically around the southern side of the cyclone (Fig. 7f). The strongest core of winds remained immediately behind the Arctic front (Fig. 2d) and had increased to $35 \mathrm{~m} \mathrm{~s}^{-1}$ over eastern Nebraska (Figs. 7e,f). The leading edge of this core descended to near $900 \mathrm{hPa}$. The strong gradient in wind speed in the RAP model coincided with the strong gradient between locations that experienced high winds at the surface and those locations that did not (Fig. 3).

\section{b. Cross sections and the evolution of the elevated wind maximum}

To understand more about the evolution of the high winds, cross sections in the RAP model were created along line $\mathrm{AB}$, which extends west-east along the Colorado-Wyoming border into central Nebraska (Figs. 8 and 9). A $15 \mathrm{~m} \mathrm{~s}^{-1}$ wind maximum was present within the saturated air above $x=100 \mathrm{~km}$, immediately west of the Front Range and Laramie Mountains between 750 and $650 \mathrm{hPa}$ on isentropic surfaces of $\theta=290-295 \mathrm{~K}$ (Figs. 9a,b). This wind maximum strengthened to $20 \mathrm{~m} \mathrm{~s}^{-1}$ by 1700 UTC as it crested the mountains (Fig. 9c). The wind maximum continued to strengthen to $30 \mathrm{~m} \mathrm{~s}^{-1}$ at $x=330 \mathrm{~km}$ just above $700 \mathrm{hPa}$ (Fig. 9e), and by 1900 UTC its leading edge began descending onto the high plains to the east. The downwind edge of the $25 \mathrm{~m} \mathrm{~s}^{-1}$ contour was immediately west of the Colorado-Nebraska border. The southward-surging Arctic air mass $(\theta=292 \mathrm{~K}$ and 


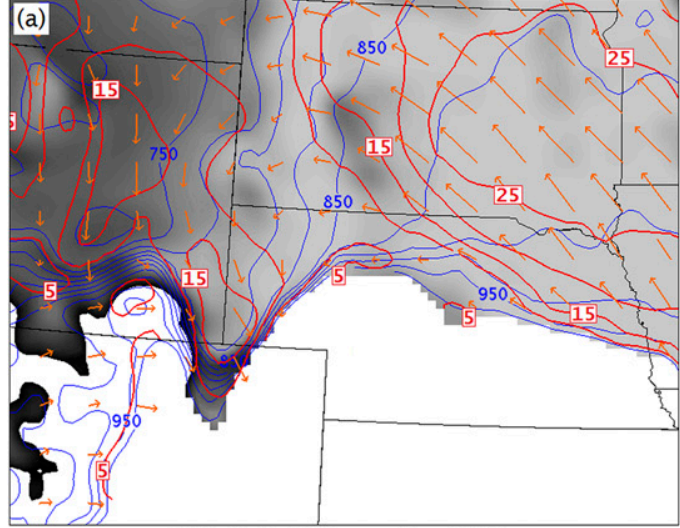

1900 UTC 25 December 2016

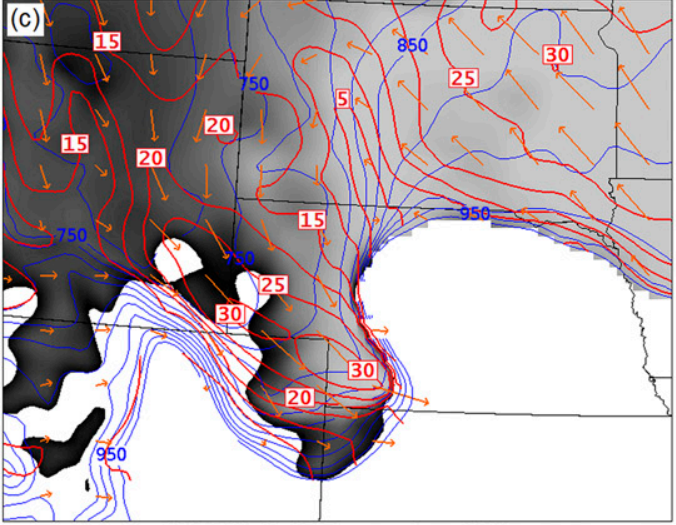

2300 UTC 25 December 2016

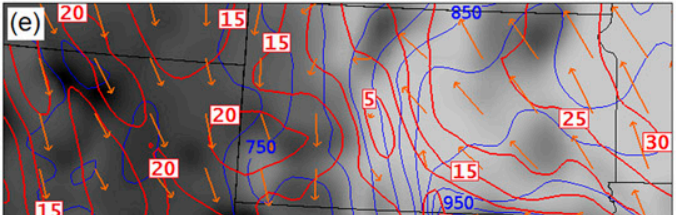

15

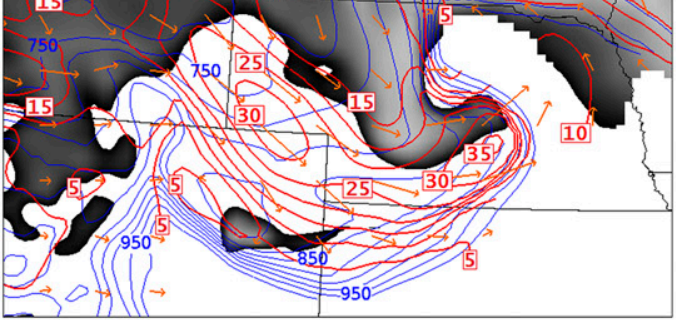

0100 UTC 26 December 2016

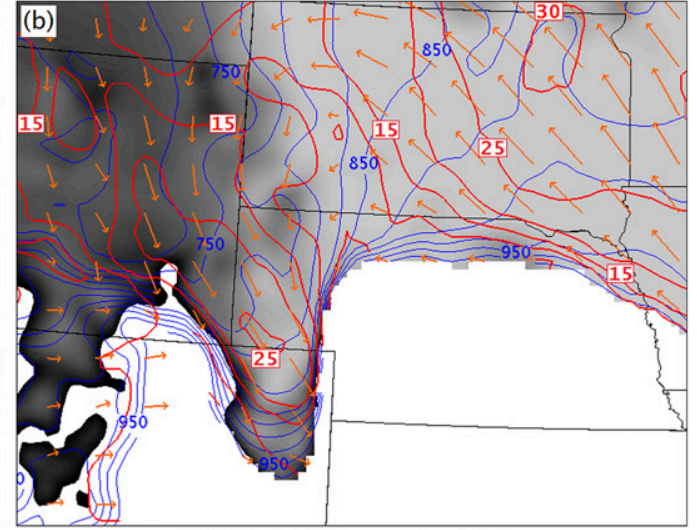

2100 UTC 25 December 2016

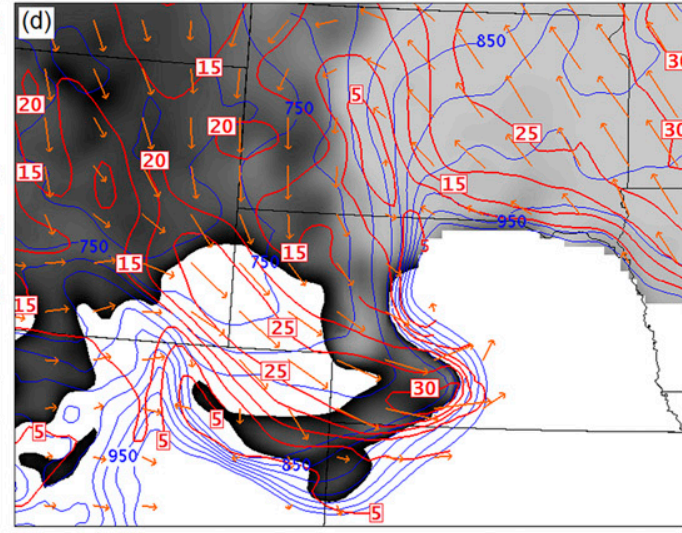

0000 UTC 26 December 2016

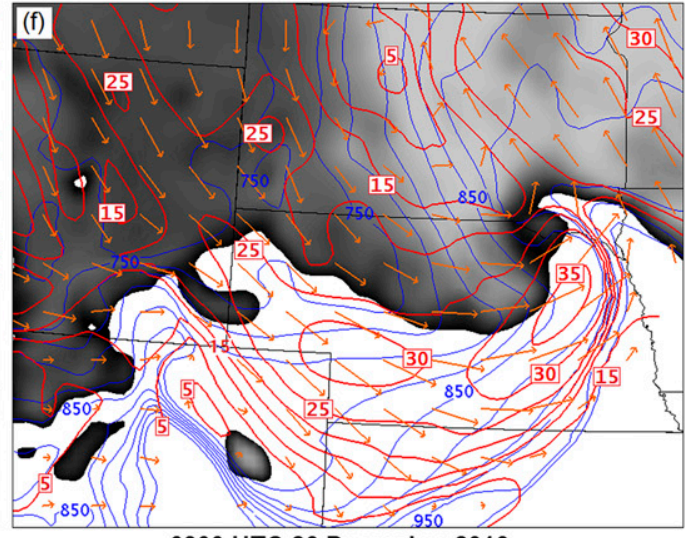

0300 UTC 26 December 2016

FIG. 7. RAP model relative humidity (shaded from dark gray at $80 \%$ to light gray at $100 \%$ ), pressure (blue contours every $25 \mathrm{hPa}$ ), wind speed (red contours every $5 \mathrm{~m} \mathrm{~s}^{-1}$ ), and wind vectors on the $285-\mathrm{K}$ surface for (a) 1900 UTC 25 Dec, (b) 2100 UTC 25 Dec, (c) 2300 UTC 25 Dec, (d) 0000 UTC 26 Dec, (e) 0100 UTC 26 Dec, and (f) 0300 UTC 26 Dec 2016. All fields from each time are from that hour's RAP model initialization.

less) also entered the plane of the cross section by 1900 UTC (Fig. 9f).

By 2100 UTC, this wind maximum continued to grow and strengthen, becoming elevated over the stable layer capping the Arctic frontal zone (Figs. 9g,h). Maximum winds had increased to $35 \mathrm{~m} \mathrm{~s}^{-1}$ at $x=450 \mathrm{~km}$ between
700 and $600 \mathrm{hPa}$ above the Arctic air mass. Winds exceeding $25 \mathrm{~m} \mathrm{~s}^{-1}$ encompassed the area from $550 \mathrm{hPa}$ to the top of the boundary layer (Figs. 9g,h). While its upstream edge remained fixed to the crest of the mountains, its leading edge continued moving downstream (Fig. 9g). 


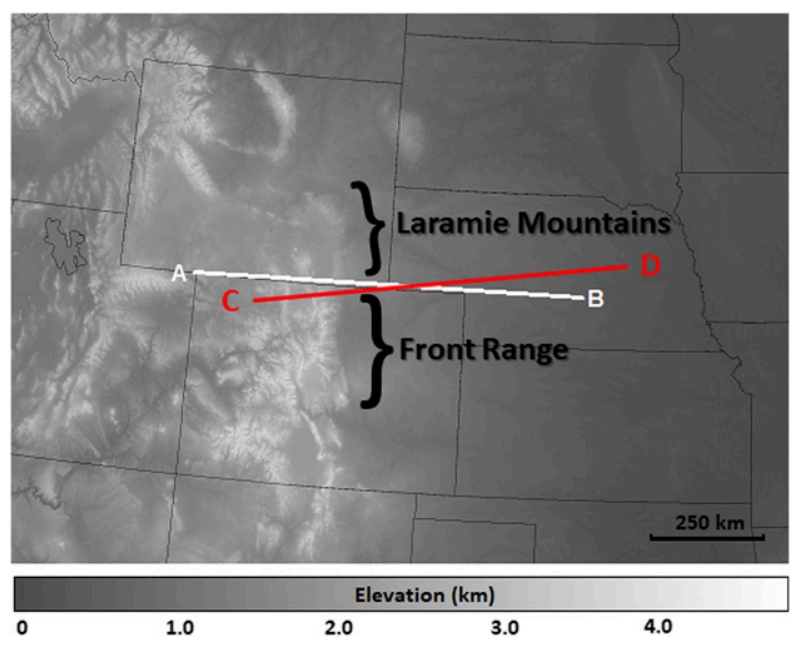

FIG. 8. Topographic map. Line AB indicates the plane of cross sections in Fig. 9. Line CD indicates the plane of cross sections in Fig. 11.

By 2300 UTC, the core of the 25 and $30 \mathrm{~m} \mathrm{~s}^{-1}$ winds expanded farther (Figs. 9i,j). The area encompassed by the $25 \mathrm{~m} \mathrm{~s}^{-1}$ contour extended slightly above $500 \mathrm{hPa}$, and the leading edge of $30 \mathrm{~m} \mathrm{~s}^{-1}$ contour descended to just above the boundary layer near $x=620 \mathrm{~km}$ (Figs. 9i,j). The relative humidity began decreasing below $80 \%$ just downstream of the highest mountain peaks (Fig. 9i).

By 0100 UTC, the leading edge of the wind maximum moved northeast out of the plane of the cross section (cf. Figs. 9k and 7c,d). An extensive portion of the elevated wind maximum became unsaturated from the lee side of the mountains into southwest Nebraska (Fig. 9k). A large core of winds exceeding $25 \mathrm{~m} \mathrm{~s}^{-1}$ remained within the upwind portion of the wind maximum, indicating this was not a transient feature that crested the mountains and moved downstream. Instead, the western extent of this wind maximum remained anchored to the lee side of the mountains, even as its leading edge surged far downstream and wrapped into the departing cyclone. In fact, the 0400 UTC RAP model forecast valid for 1000 UTC 26 December showed that winds on the $285-\mathrm{K}$ isentropic surface were forecast to remain $25-30 \mathrm{~m} \mathrm{~s}^{-1}$ in northern Colorado and southeastern Wyoming, with a swath of $25 \mathrm{~m} \mathrm{~s}^{-1}$ winds extending from the Front Range and Laramie Mountains all the way to Minnesota (Fig. 10).

\section{c. Factors determining the western and eastern edges of the elevated wind maximum}

The origin of the wind maximum immediately downwind of the Laramie Mountains and the persistence of the western edge of the wind maximum in the lee indicates that this elevated wind maximum was associated with mountain waves. Conditions were favorable for the development of mountain waves and severe downslope winds, with high pressure southwest of Colorado and low pressure to the northeast (e.g., Lee et al. 1989). This pressure configuration is not a guarantee that mountain waves and severe downslope winds will occur, but it is consistent with all of the cases that Lee et al. (1989) examined. One of the most important variables in determining the likelihood of severe downslope winds is the 700-hPa geostrophic wind. In this case, the 700-hPa geostrophic wind over north-central Colorado was $310^{\circ}$ at $17 \mathrm{~m} \mathrm{~s}^{-1}$ at 2100 UTC 25 December, consistent with the wind speed and direction favorable for Colorado downslope windstorms (e.g., Lee et al. 1989; Durran 1990). Indeed, a downslope windstorm did occur in the lee of the Laramie Mountains in Wyoming and over parts of northeast Colorado Christmas afternoon and night. For example, the highest measured leeside wind gust was $49 \mathrm{~m} \mathrm{~s}^{-1}$ at Gold Hill, Colorado (Fig. 3). Winds at Rocky Flats National Wildlife Refuge peaked at $41 \mathrm{~m} \mathrm{~s}^{-1}$, and $40 \mathrm{~m} \mathrm{~s}^{-1}$ winds were measured at the NCAR Mesa Laboratory in Boulder, Colorado (NOAA/ESRL PSD 2016).

Although the western edge of this mesoscale wind maximum was anchored in the lee of the Rockies, the eastern extent extended quite far away from the mountains. Most downslope windstorms rarely extend more than about $35 \mathrm{~km}$ away from the slope, as has been documented in observational (e.g., Brinkmann 1974) and modeling studies (e.g., Lee et al. 1989; Miller and Durran 1991; Doyle and Durran 2002). In this case, however, the elevated wind maximum that originated downstream of the mountain waves extended $850 \mathrm{~km}$ away from the mountains to central Minnesota. What could cause this extension of the elevated jet away from the mountains? One potential answer is the presence of the Arctic front.

Richard et al. (1989) examined the influence of friction on downslope windstorms and found that friction is what limits downstream extent, confining the extreme winds to a small area on the lee slope (cf. their Figs. 2 and 3). In each of the modeling studies, downslope windstorms were examined with a free-slip condition applied at the surface in most of the simulations. The results showed the strong downslope maximum developing on the lee side, with the leading edge of the strongest winds moving away from the mountain (see Fig. 4 from Lee et al. 1989 for another example). Similar to these numerical simulations, the highly stable Arctic frontal zone in the Christmas 2016 cyclone provided an effective free-slip surface, allowing the mesoscale wind maximum to be transported far downstream from its 
origination point and to be drawn into the cyclone. In addition, just as in these simulations, the western edge of the extreme winds remained tied to the lee side of the mountain, even as the leading edge moved downstream. Menchaca and Durran (2017) simulated downslope winds that occurred as an idealized extratropical cyclone migrated across a north-south-oriented ridge and found that cross-mountain winds along the northern portion of the ridge remained strong for a couple days after cyclone passage. The 6-h forecast from the 0400 UTC 26 December RAP model, valid for 1000 UTC, indicated west-northwest winds would still be at least $30 \mathrm{~m} \mathrm{~s}^{-1}$ near the Colorado-Wyoming border (Fig. 10). Severe downslope winds occurred through the night of 25 December, with the final gust of at least $25 \mathrm{~m} \mathrm{~s}^{-1}$, at the NCAR Mesa Laboratory, occurring at 1015 UTC 26 December (B. Rilling 2017, personal communication).

Why did the high winds at the surface end over southwestern Minnesota (cf. Figs. 3 and 10)? One possible answer is the winds around the cyclone were not as close to the surface as earlier, and therefore were not capable of being mixed to the surface as the stable Arctic air encircled the low center. The last wind gust of $25 \mathrm{~m} \mathrm{~s}^{-1}$ or more occurred at Redwood Falls, Minnesota, (RWF) at 0600 UTC 26 December. The closest observed sounding was launched $6 \mathrm{~h}$ later at Chanhassen, Minnesota, and that sounding indicated winds of at least $25 \mathrm{~m} \mathrm{~s}^{-1}$ were at $1524 \mathrm{~m} \mathrm{AGL}$ and above (not shown). That height was $100 \mathrm{~m}$ above the frontal inversion. By comparison, when the highest wind gust occurred at McCook, Nebraska, a RAP model analysis sounding showed that winds of at least $25 \mathrm{~m} \mathrm{~s}^{-1}$ were only $91 \mathrm{~m}$ AGL (not shown).

After the high winds ceased over Minnesota, RAP model analysis soundings continued to indicate winds equaling or exceeding $25 \mathrm{~m} \mathrm{~s}^{-1}$ would remain below the inversion, suggesting that high winds would still be mixed to the surface. Comparing the observed Chanhassen, Minnesota, sounding with a 6-h forecast sounding from the 0600 UTC cycle of the RAP model (not shown) revealed that the RAP model was too low with the height of the winds greater than or equal to $25 \mathrm{~m} \mathrm{~s}^{-1}$ (424 m AGL). That was $1100 \mathrm{~m}$ lower than where the Chanhassen sounding observed $25 \mathrm{~m} \mathrm{~s}^{-1}$ winds, suggesting the RAP model could no longer be relied upon for diagnosing the potential for low-level winds to be mixed to the surface.

\section{d. Cross sections showing mountain waves}

The grid spacing of the RAP model is too coarse to accurately capture mountain waves. Therefore, a realtime WRF-ARW (Skamarock et al. 2008) forecast from Colorado State University was used to further diagnose aspects of this event. This configuration of WRF-ARW has been used for experimental forecasts for several years, including in support of field campaigns (e.g., Schumacher 2015; Stelten and Gallus 2017. The forecast presented here used version 3.8.1 of WRF-ARW. Forecasts from the NCEP Global Forecast System (GFS) were used as initial and lateral boundary conditions, with the lateral boundary conditions updated every $3 \mathrm{~h}$. The horizontal grid spacing was $4 \mathrm{~km}$ with a single domain that covered much of the western and central United States, with 51 vertical levels on a stretched grid, and the time step was $25 \mathrm{~s}$. The physical parameterizations included the Mellor-Yamada-Janjić PBL parameterization (Mellor and Yamada 1982; Janjić 2002), two-moment cloud microphysics parameterization (Morrison et al. 2009), Noah land surface model (Chen and Dudhia 2001), and Rapid Radiative Transfer Model for GCMs (Iacono et al. 2008). Convective motions were treated explicitly rather than parameterized.

Inspection of the WRF output shows the location and timing of the strong winds was comparable between the RAP and WRF, indicating the WRF is suitable for studying the structure and evolution of the strong winds. However, the WRF wind speeds were $5-10 \mathrm{~m} \mathrm{~s}^{-1}$ less than winds from RAP model analyses and observed peak wind gusts at the surface (cf. Figs. 9 and 11). The weak forecast winds were indicative of the difficulties the models were having simulating high winds, both at the surface and within the elevated jet, especially with increasing lead time.

Cross sections were taken along line CD (Fig. 11, with the cross-section location in Fig. 8). At 2100 UTC 25 December, mountain waves were in progress and amplifying (Figs. 11a,b). Between 2100 and 0000 UTC, the $303-\mathrm{K}$ isentrope rapidly lowered from 5 to $3 \mathrm{~km}$ MSL, and winds increased from 35 to $45 \mathrm{~m} \mathrm{~s}^{-1}$ on the lee slope. Immediately downstream of the primary mountain wave, winds increased to more than $30 \mathrm{~m} \mathrm{~s}^{-1}$, but farther downstream, just above the Arctic air mass, the WRF model predicted winds between 20 and $25 \mathrm{~m} \mathrm{~s}^{-1}$. Although the magnitude of the WRF model winds was not as strong as what occurred at the surface, the output provided evidence that mountain waves occurred and that high winds existed well downstream, albeit above the surface in the model.

\section{e. The origin of the elevated wind maximum}

In the numerical modeling studies referred to earlier (Lee et al. 1989; Richard et al. 1989), high winds associated with the simulated downslope windstorms moved downstream from the lee slope in continuous fashion because of the lack of friction. However, friction would be a factor in the evolution of a real event where the Arctic air was not present. The WRF model simulation 

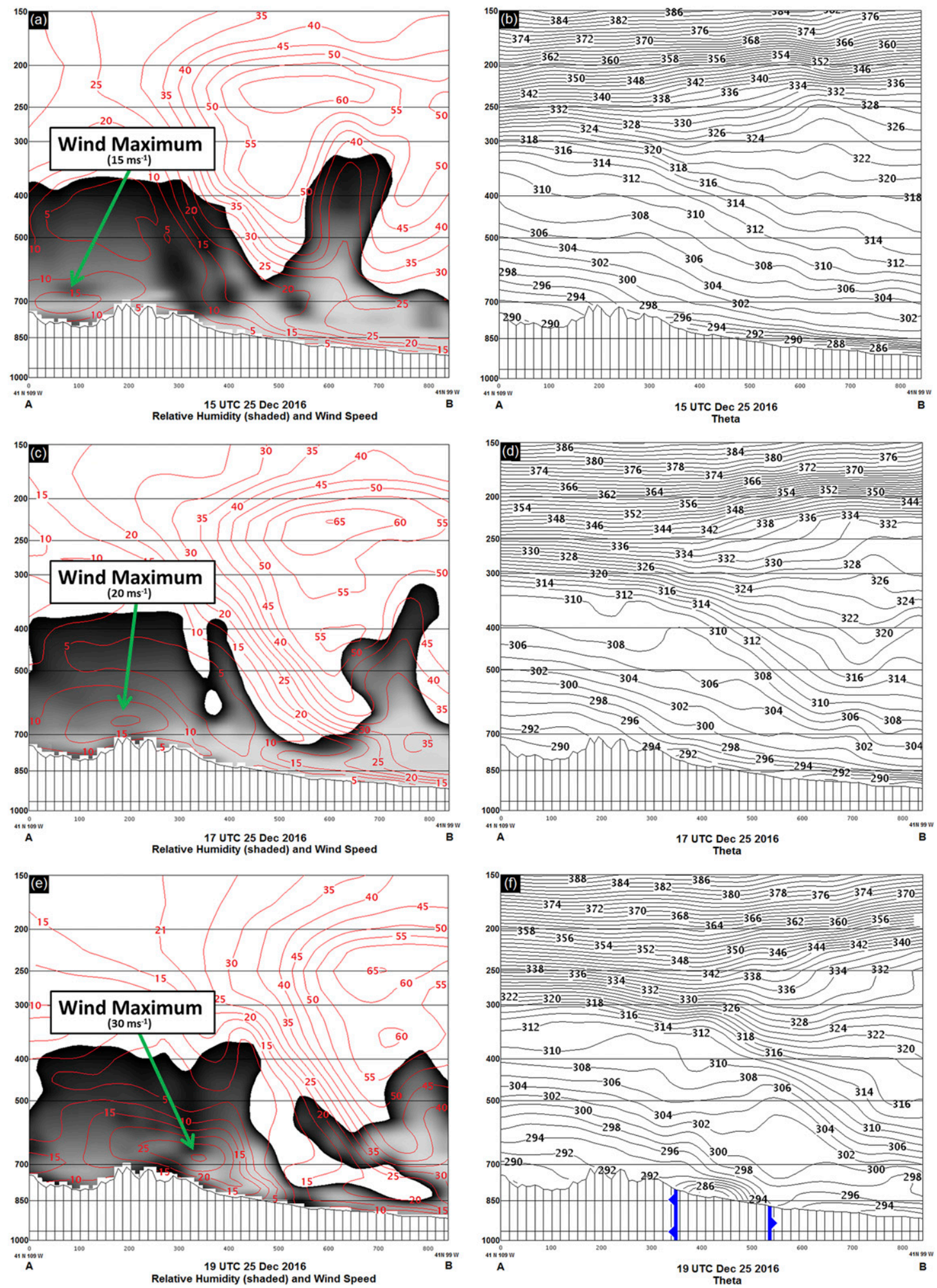

FIG. 9. Vertical cross sections through the mesoscale wind maximum at (a),(b) 1500 UTC, (c),(d) 1700 UTC, (e),(f) 1900 UTC, (g),(h) 2100 UTC, and (i),(j) 2300 UTC 25 Dec, and (k),(l) 0100 UTC 26 Dec 2016 (vertical axis pressure in hPa; horizontal axis in $\mathrm{km}$ ). (left) Wind speed (solid red lines every $5 \mathrm{~m} \mathrm{~s}^{-1}$ ) and relative humidity shaded from black ( $80 \%$ ) to light gray (100\%). (right) Potential temperature (K). Traditional cold front symbols are used to subjectively depict the western and eastern boundaries of the Arctic air mass. All fields from RAP model initializations. 

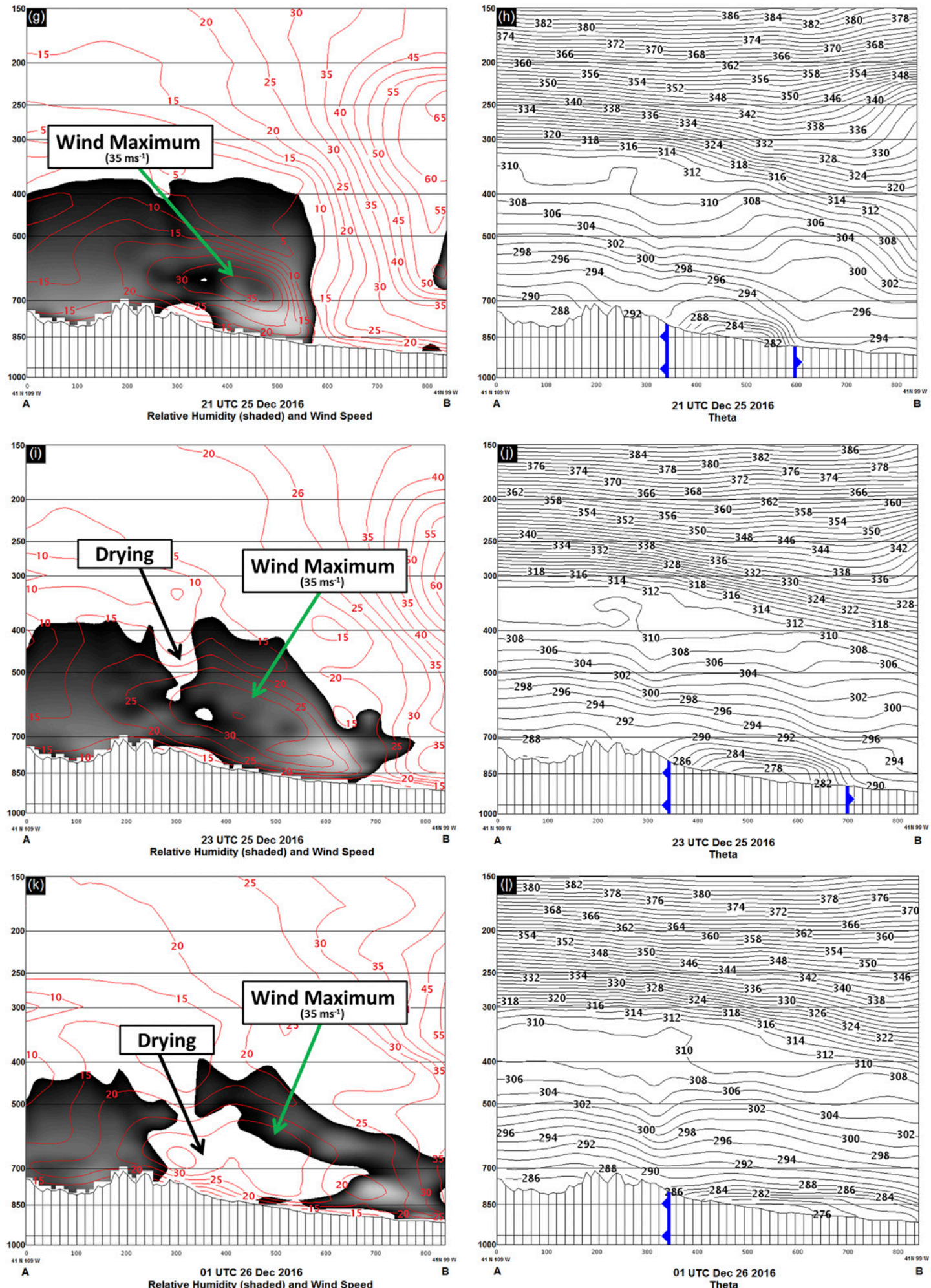

FIG. 9. (Continued) 


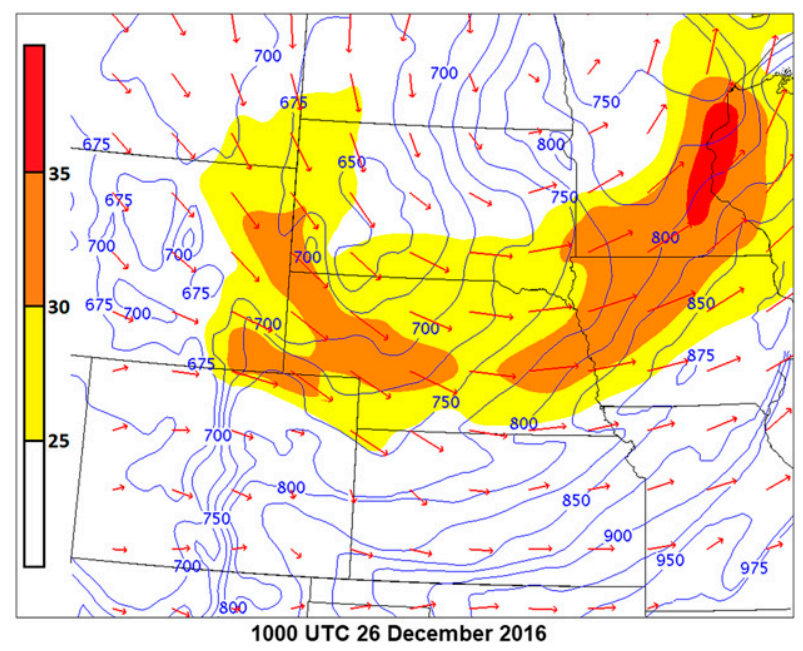

FIG. 10. The 6-h forecast from 0400 UTC 26 Dec 2016 RAP model valid for 1000 UTC. Wind speed (shaded according to scale; $\mathrm{m} \mathrm{s}^{-1}$ ), pressure (blue contours; $\mathrm{hPa}$ ), and wind vectors on $285-\mathrm{K}$ potential temperature surface.

in this study indicates the downslope windstorm remained on the lee slope (Fig. 11b). This is supported by observations as high winds were not continuous across northeastern Colorado (Fig. 3). A gap existed between the downslope windstorm at and near Boulder, Colorado, and where the first observed high wind gust occurred in association with the mesoscale wind maximum at Sterling, Colorado. For example, the highest wind gust measured at the Denver International Airport (which is $55 \mathrm{~km}$ southeast of Boulder) was only $17 \mathrm{~m} \mathrm{~s}^{-1}$. The WRF model simulation shows this gap, indicating the front and Arctic air mass would be east of the lee slope (Fig. 11b). In order for the downslope windstorm to be responsible for the mesoscale wind maximum, the Arctic front would have needed to be farther west. The front did not pass through Denver until 0000 UTC 26 December (Fig. 2c). By that time, high winds associated with the mesoscale wind maximum had been in progress east of Denver for $4 \mathrm{~h}$.

Another area of wind speeds exceeding $25 \mathrm{~m} \mathrm{~s}^{-1} \mathrm{de}-$ veloped immediately downstream of the main mountain wave in the WRF model simulation, and those winds extended downstream atop the Arctic air mass (Figs. 11a,b). In previous studies, an elevated jet has been observed (Neiman et al. 1988) and modeled (Miller and Durran 1991) above the boundary layer when mountain waves were present. One of the Miller and Durran (1991) simulations that included surface friction showed an elevated secondary wind maximum existed downstream of where the downslope windstorm terminated (see their Fig. 15a at $x=3.5, y=1$ ). We believe this elevated jet is the origination point for the mesoscale wind maximum in this case.

If this elevated jet was passively drawn into the cyclone's circulation, what maintained and even increased the wind speeds at the leading edge of the mesoscale wind maximum (Figs. 7c-f)? We hypothesize the high winds were supported by the intense horizontal pressure gradients in the flow south of the low center. This is illustrated by the Montgomery streamfunction $\left(\Psi=c_{p} T+g z\right)$ at 2100 and 2300 UTC 25 December 2016 on the 290-K isentropic surface, which lies just at the top of the Arctic
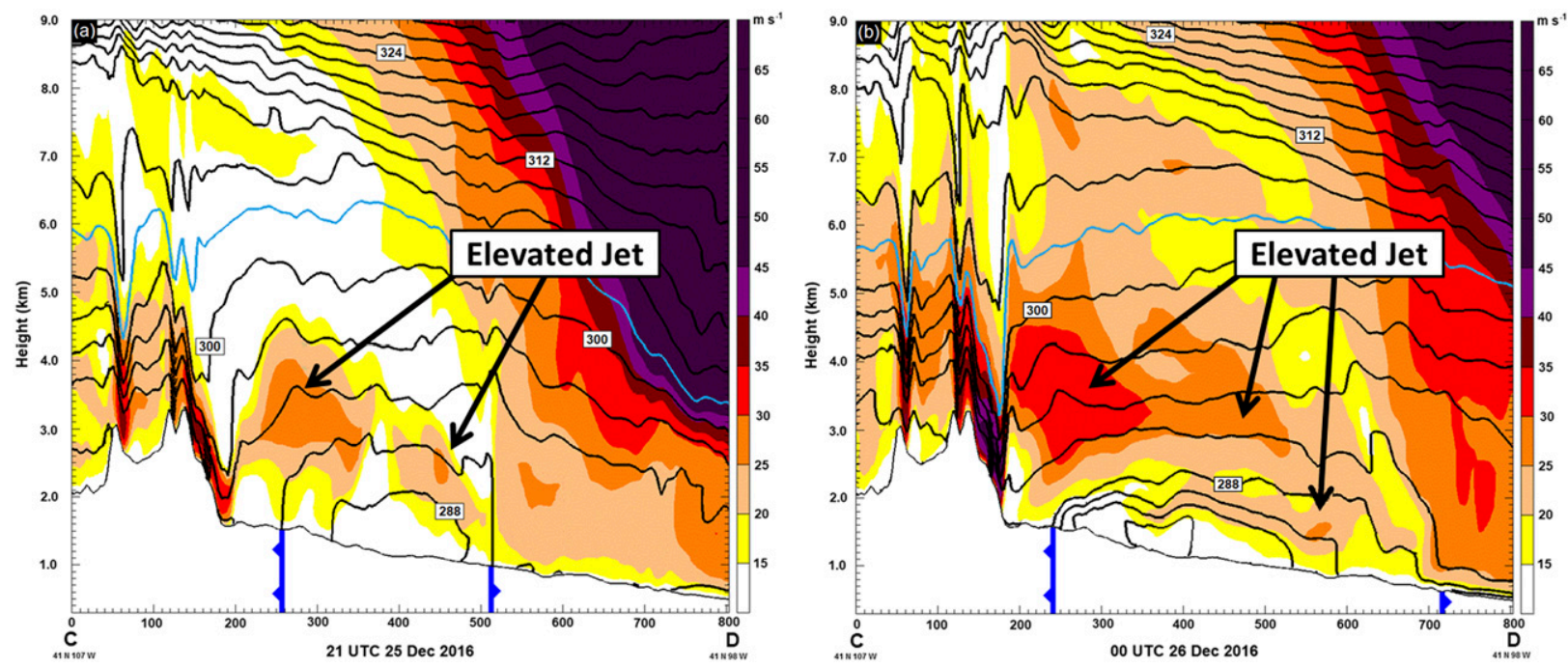

FIG. 11. Vertical cross sections through the mountain waves at (a) 2100 UTC 25 Dec 2016 and (b) 0000 UTC 26 Dec 2016. Locations shown in Fig. 8 (vertical axis is height in km MSL). Wind speed (shaded according to scale), and potential temperature (solid black lines every $3 \mathrm{~K}$ ) with the $303-\mathrm{K}$ isentrope colored light blue. Traditional cold front symbols are used to subjectively depict the western and eastern boundaries of the Arctic air mass. All fields are derived from a WRF-ARW model simulation initialized at 0000 UTC 25 Dec 2016. 


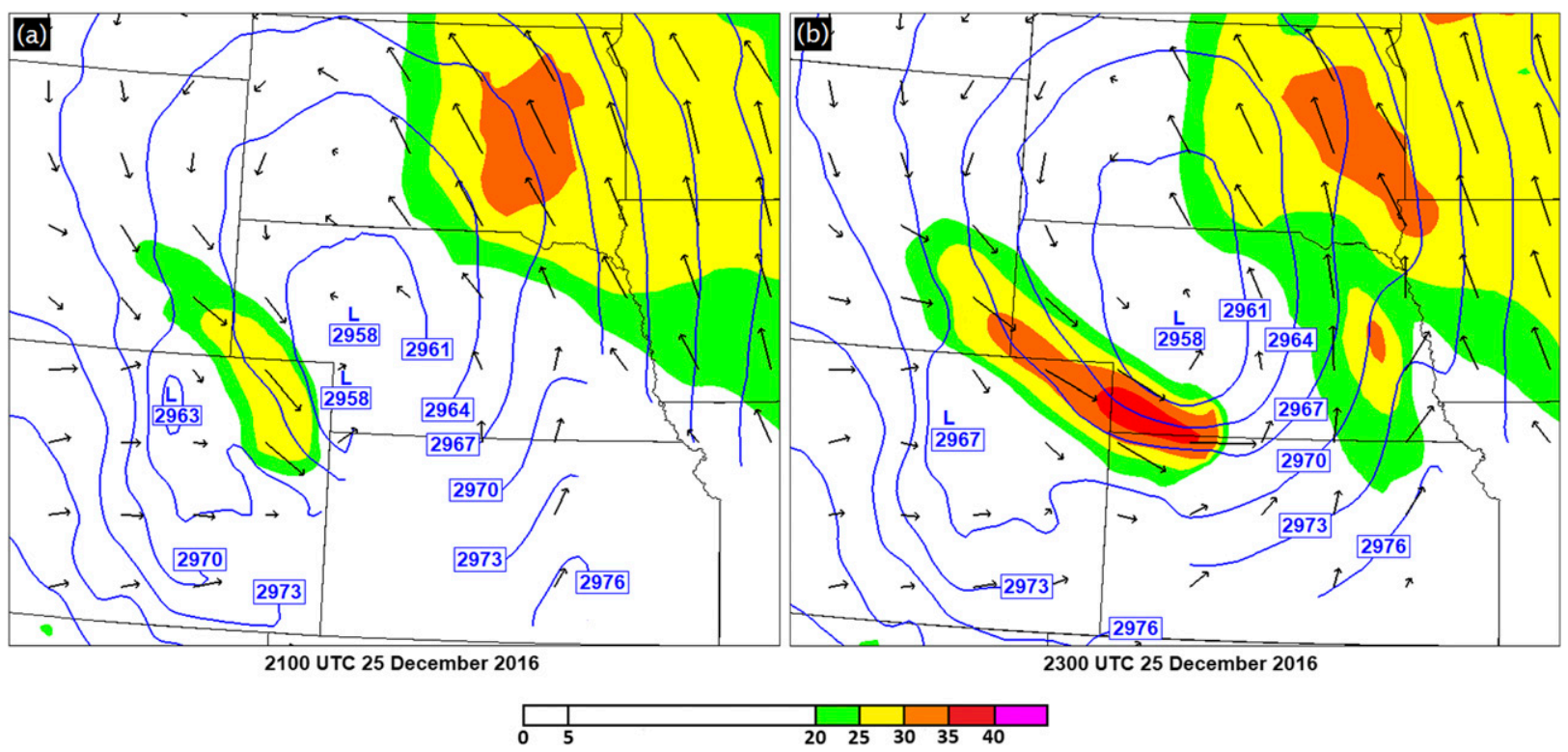

FIG. 12. RAP model initialization at (a) 2100 and (b) 2300 UTC 25 Dec 2016. Wind speed (shaded according to scale; $\mathrm{m} \mathrm{s}^{-1}$ ), wind vectors, and Montgomery streamfunction (blue contours in $100 \mathrm{~m}^{2} \mathrm{~s}^{-2}$ ) on the $290-\mathrm{K}$ potential temperature surface.

air (Figs. 12 and 9h,j). At 2100 UTC, as also shown by the vertical cross section in Fig. 9g, the high winds were just beginning to extend eastward from the mountain wave above the Arctic front. On the $290-\mathrm{K}$ isentropic surface, a moderately strong jet with maximum winds in the range $25-30 \mathrm{~m} \mathrm{~s}^{-1}$ extended from the mountains to an area southwest of the low center. The contours of $\Psi$ to the west of the low center were not tightly organized around the low, and the wind in extreme southeastern Wyoming was strongly ageostrophic.

By 2300 UTC, the jet of high winds strengthened, elongated, and wrapped farther around the low center, extending from the lee of the Laramie Mountains to the Kansas-Nebraska border. Winds in the range $35-39 \mathrm{~m} \mathrm{~s}^{-1}$ were present south of the low at the leading edge of this jet, where the extremely tight isentropic gradient in $\Psi$ supported a geostrophic wind of approximately $80 \mathrm{~m} \mathrm{~s}^{-1}$. It is not surprising that the actual winds in this cyclonically curved flow were subgeostrophic, particularly since they would not have had time to come into balance; nevertheless, this gradient in $\Psi$ is more than adequate to preserve the strength of the winds, originally generated by the downslope flow, as they move around the low center.

\section{Similarity of the surface wind maximum to a sting jet}

The strong winds in the Christmas 2016 windstorm initially piqued our attention because of their superficial similarity to a sting jet (e.g., Browning 2004; Clark et al. 2005; Schultz and Sienkiewicz 2013; Smart and Browning
2014; Schultz and Browning 2017; Clark and Gray 2018). Sting jets are found at the frontolytic end of the bent-back front (Schultz and Sienkiewicz 2013) associated with Shapiro-Keyser-type extratropical cyclones (Shapiro and Keyser 1990). Sting jets last only a few hours, have a mesoscale-sized footprint of strong winds at the surface, and form in the midtroposphere within the cloud head. The air that becomes the sting jet descends to the top of the boundary layer while wrapping around the equatorial side of a deep cyclone. Initially saturated, air parcels traveling around the cyclone accelerate as they descend because of the stronger horizontal pressure gradients at low levels south of the low center (e.g., Slater et al. 2015, 2017) and may cool from evaporation as they become unsaturated (Clark et al. 2005; Baker et al. 2014). Damaging surface winds occur where steep lapse rates associated with cold-air advection reduce static stability leading to the mixing of momentum to the surface, near the tip of the comma head (e.g., Browning 2004; Browning and Field 2004; Browning et al. 2015; Slater et al. 2017). Sting jets-the manifestation of these accelerated winds at the surface - then disappear with the associated strong surface winds being replaced when the cold conveyor belt nearly encircles the cyclone center.

Given these similarities, a reasonable question was whether this mesoscale wind maximum was associated with a sting jet. Although the Arctic front did not form in the same way as a bent-back front in a Shapiro-Keyser cyclone, there was some structural similarity (Fig. 2). The swath of winds had a mesoscale dimension and was distinct from the strong winds associated with the cold 
conveyor belt (Fig. 3). The winds occurred on the equatorward side of an extratropical cyclone and appeared to emerge from accelerating and descending air, which evaporated the cloud head (Figs. 5 and 7).

Despite these similarities, there are some clear differences between the Christmas 2016 mesoscale wind maximum and the sting-jet conceptual model. First, the Christmas 2016 cyclone-not being a Shapiro-Keyser cyclone-possessed no frontolytic bent-back front, a feature common to sting jets (e.g., Schultz and Sienkiewicz 2013). Second is the origin of the wind maximum. Backward air-parcel trajectories (not shown) revealed that air parcels originating in this surface mesoscale wind maximum originated west of the Front Range of the Rockies in the midtroposphere, became saturated in the cloud head, and then descended below the cloud, both cooling and drying. The westerly origin of this air was because the trough in the jet stream was an open wave (Fig. 1). In previously published examples of sting jets (e.g., Fig. 2 in Slater et al. 2017), however, air in sting jets arrives from the east, indicative of deep cyclonic warm conveyor belt flow as would be expected if the trough aloft had already become closed. Third is that the wind maximum formed in a very local region around 1900 UTC downstream of the Laramie Mountains of southeast Wyoming (Fig. 7a) and grows downstream over time from that location, remaining anchored in the lee of the mountains (Figs. 7b-d). Thus, given the small scale of this wind maximum at formation, its occurrence in the lee of the Laramie Mountains, and its persistence with the western edge against the mountains, this wind maximum is not a sting jet.

A question relevant to forecasters is how the descending and accelerating winds in the mid- to lower troposphere reached the surface. The key is the observation that the strong winds in the Christmas 2016 cyclone tracked with the location of the Arctic front (Figs. 2 and 4). We hypothesize that steep lapse rates associated with cold-air advection (perhaps aided by surface sensible heat flux) and well-mixed postfrontal air facilitated downward mixing of the higher winds above the boundary layer toward the surface immediately behind the Arctic front. Mixing deeper in the cold air was prohibited by the very stable layer atop the Arctic air mass. This hypothesis is supported by observations showing that the strongest winds did not last more than $2 \mathrm{~h}$ at any one location. Mixing between the free atmosphere and the boundary layer is difficult for numerical models, which may explain model errors in this case. Although we cannot be confident that this hypothesis is true, we will present evidence in the next section that supports this argument through a comparison to a case that did not produce a surface wind maximum.

\section{Comparison to a cyclone without high winds}

To aid forecasters in distinguishing between cyclones associated with a mesoscale swath of high surface winds far away from the mountains from those not associated with such a feature, we present the case of 28 February 2012 for comparison. This case is comparable to the Christmas 2016 storm: a lee cyclone with below-average central pressure formed in almost the same place, associated with a deep upper-level trough to the west. Whereas the Christmas 2016 storm took a northerly track away from the mountains and was slightly deeper, the February 2012 storm took a northeasterly track and was slightly weaker, likely because of the weaker upperlevel trough. The principal difference is that the Christmas 2016 storm produced a mesoscale swath of high surface winds over the plains, whereas the February 2012 storm did not (Fig. 13). As we will show, we attribute this difference to the Christmas 2016 storm being associated with mountain waves, an elevated jet, and a very stable Arctic air mass, allowing the transport of high winds away from the lee slope and being brought down to the surface at the leading edge of the Arctic air. In contrast, the February 2012 storm did not produce mountain waves and severe downslope winds while the cyclone was in close proximity to the Front Range and Laramie Mountains; they occurred while the cyclone was over southwest Minnesota (NCEI 2012). Furthermore, while the February 2012 storm had a stable layer of polar air to transport strong winds away from the mountains, there was no well-defined Arctic front to mix the winds aloft down to the surface. As such, it makes a suitable counterpoint to the Christmas 2016 storm with the mesoscale wind maximum.

On 27 February 2012, a cyclone was moving eastward through the Desert Southwest with a central mean sea level pressure near $1003 \mathrm{hPa}$ (not shown). A quasistationary Arctic front extended from Nevada to the Dakotas. On 28 February, a lee cyclone formed over northeast Colorado and became the primary cyclone (Figs. 14a,b). The stationary Arctic front dissipated as the largest thermal contrast organized along the Pacificorigin cold front. The cyclone then moved into central Nebraska during the afternoon, and gradually deepened as it continued moving northeast on the night of the 28 February (Fig. 14c). By 1200 UTC 29 February, the cyclone was over southwest Minnesota with a central pressure of $986 \mathrm{hPa}$ (Fig. 14d).

The highest surface winds associated with this cyclone were lower than those observed with the Christmas 2016 cyclone (generally sustained at $10-15 \mathrm{~m} \mathrm{~s}^{-1}$, with gusts of $18-24 \mathrm{~m} \mathrm{~s}^{-1}$; cf. Figs. 3 and 13). This difference, however, was not due to a lack of strong winds aloft 


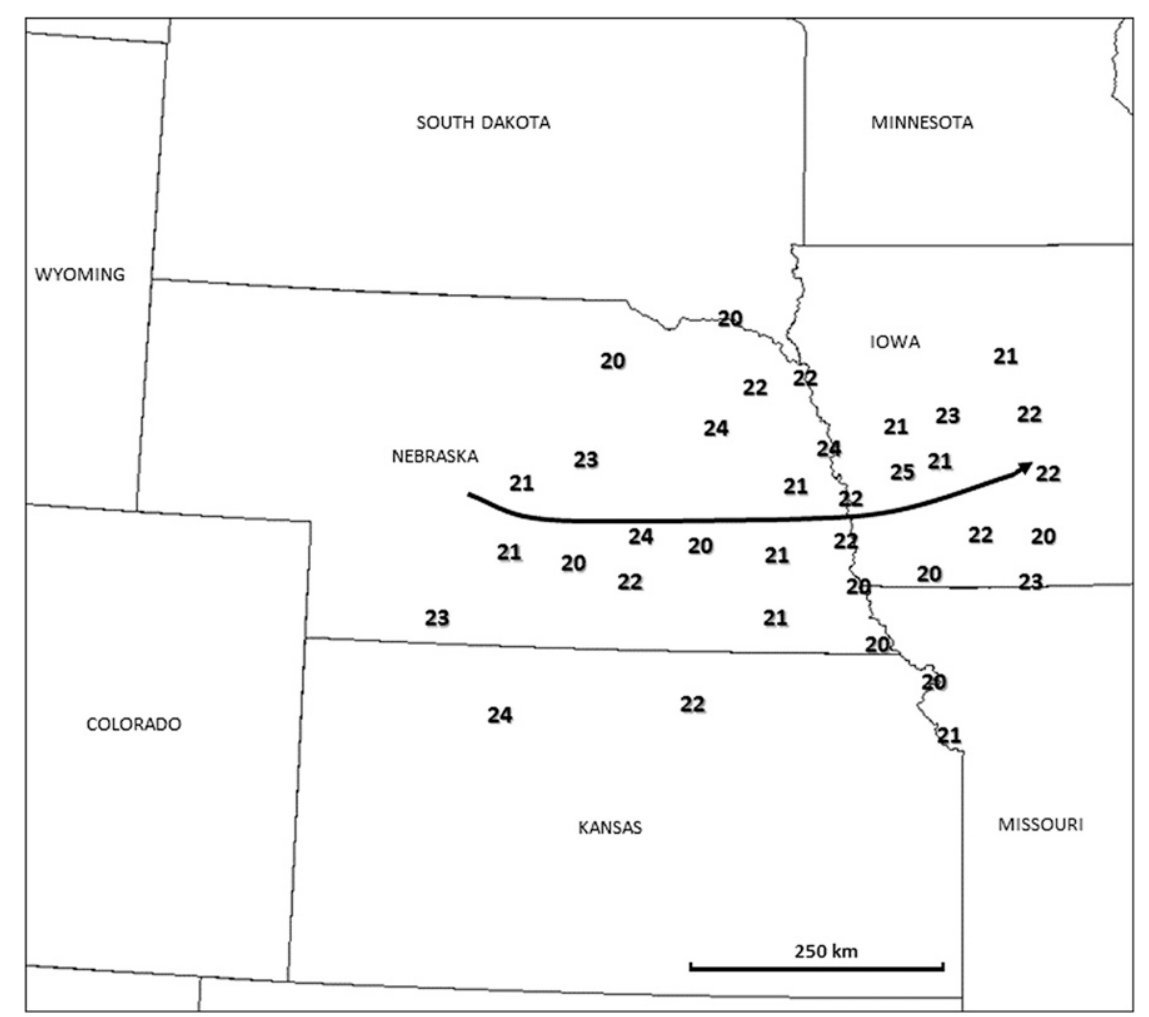

FIG. 13. Highest observed nonconvective wind gusts of $20 \mathrm{~m} \mathrm{~s}^{-1}$ and greater from 0300 to 1700 UTC 29 Feb 2012. Thick back arrow indicates the average wind direction of the peak wind gusts.

because strong gradient winds associated with the cyclone itself lay atop the polar air. At 1200 UTC 29 February, rawinsondes from Topeka, Kansas, and Omaha, Nebraska, measured 850-hPa winds of 34 and $29 \mathrm{~m} \mathrm{~s}^{-1}$, respectively (not shown). However, they occurred well behind the cold front where near-surface lapse rates were stable and mixing of the higher winds aloft was inhibited (Fig. 14d).

The Rapid Update Cycle (Benjamin et al. 2004) forecast from 0300 UTC 29 February 2012 depicts the flow aloft at 0400 and 0600 UTC on the $290-\mathrm{K}$ isentropic surface (Fig. 15). The winds, the position of the low, and the associated gradient in $\Psi$ at 0600 UTC were roughly similar to those at 2300 UTC in the Christmas storm (cf. Figs. $12 b$ and 15b). Nevertheless, there were several important differences. First, the winds were about $5 \mathrm{~m} \mathrm{~s}^{-1}$ weaker in the 29 February case. Second, they were not so clearly connected to the Laramie Mountains at the upstream end of the jet, and the deceleration of the winds downstream from the jet maximum was much more gradual. In contrast, the abrupt downstream termination of the jet on 290-K surface, in the Christmas storm, was consistent with the high winds aloft abruptly decelerating as they mix down to the surface at the Arctic front.
The biggest difference between these two cases was, however, their evolution. Just $2 \mathrm{~h}$ earlier, much larger differences were apparent on the $290-\mathrm{K}$ isentropic surface (cf. Figs. 12a and 15a). At 0400 UTC 29 February, the winds were roughly $5 \mathrm{~m} \mathrm{~s}^{-1}$ stronger than at $2100 \mathrm{UTC}$ in the Christmas case, and they were more nearly in geostrophic balance with the $\Psi$ field. Such winds would be consistent with large-scale dynamics producing the jet in the 29 February case, instead of accelerations in a downslope windstorm.

More generally, cyclone location and strength are highly variable when mountain waves and severe downslope windstorms occur. Of the 70 downslope wind events compiled by Lee et al. (1989), the cyclones associated with 59 of them occurred within the area shown in Fig. 3 of this study. When severe downslope winds were occurring, all but three of these cyclones were along or poleward of $40^{\circ} \mathrm{N}$ (which runs along the Kansas-Nebraska border), and 31 of them were clustered over western Nebraska and eastern Wyoming. The rest were scattered over Montana, North and South Dakota, Minnesota, and Iowa. The Twentieth Century Reanalysis (Compo et al. 2011) and North American Regional Reanalysis (Mesinger et al. 2006) were used to 


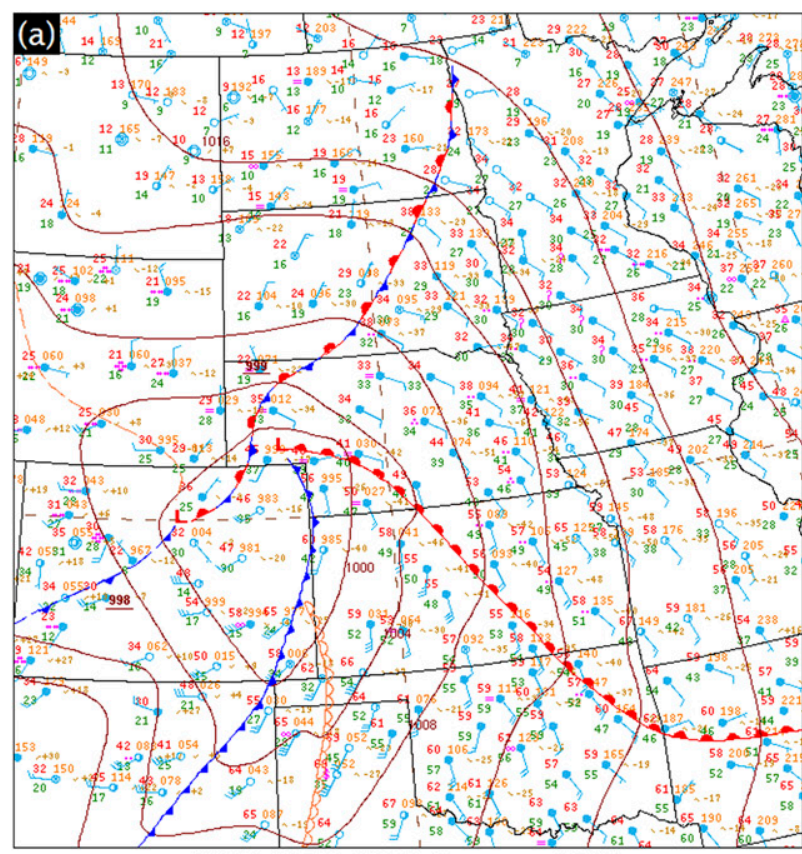

1800 UTC 28 February 2012

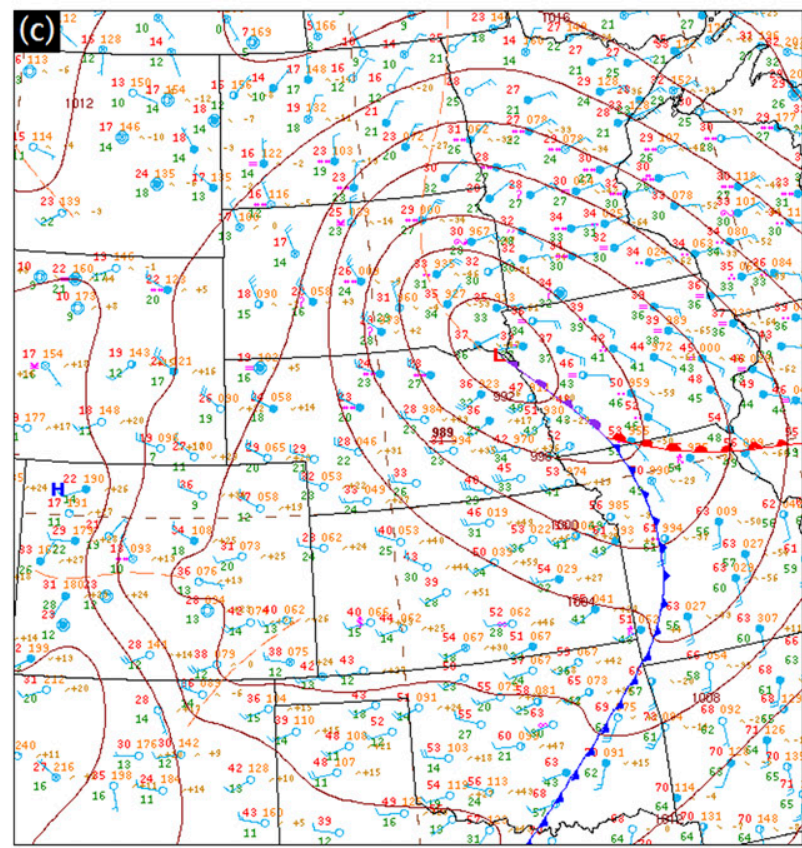

0600 UTC 29 February 2012

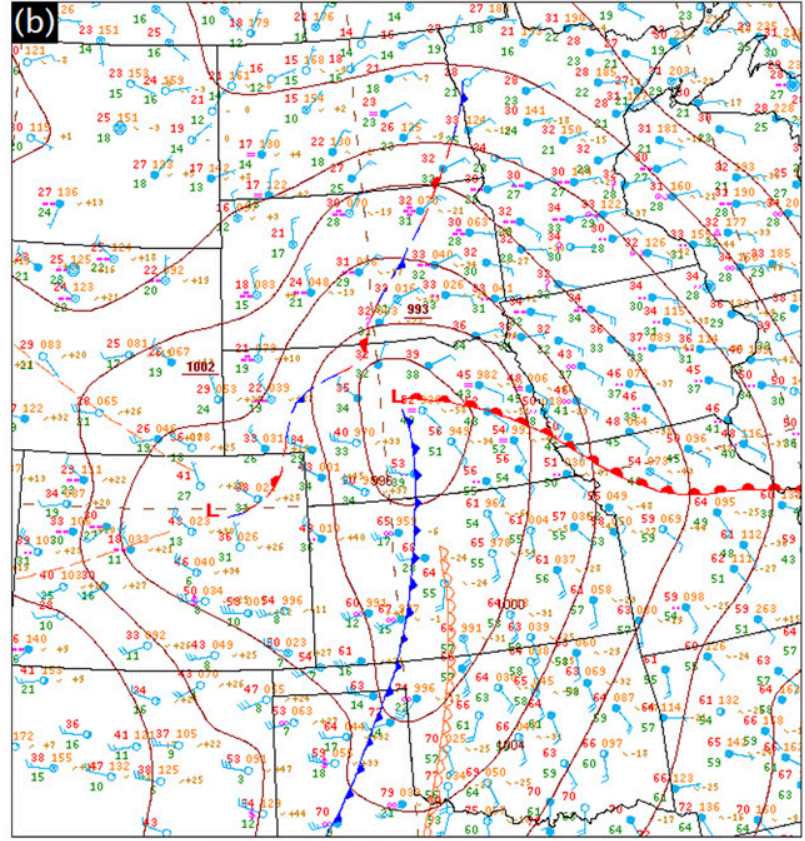

0000 UTC 29 February 2012

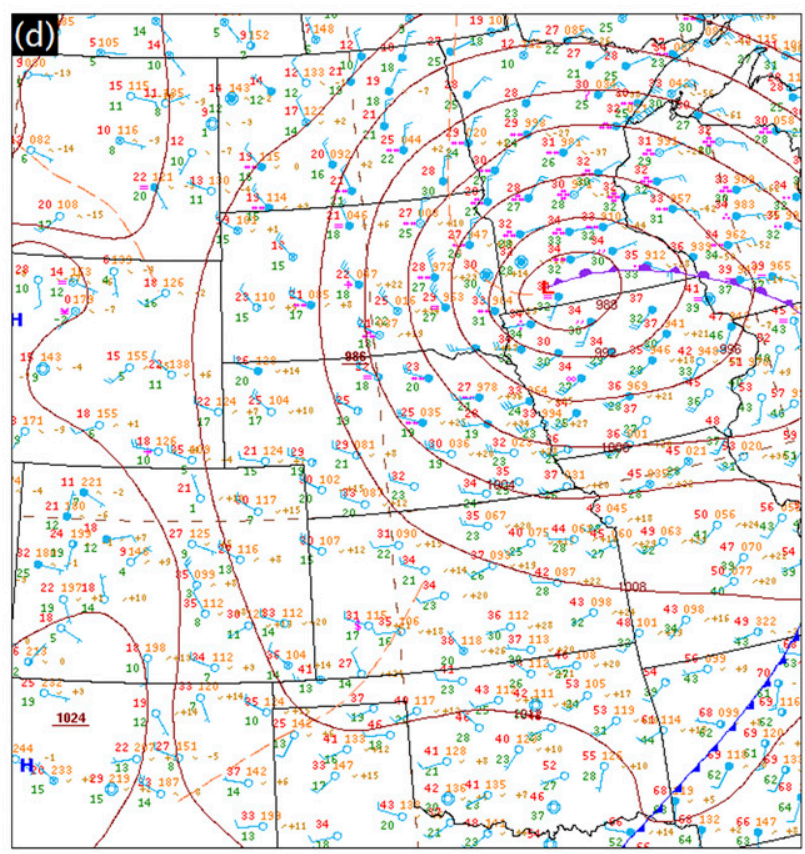

1200 UTC 29 February 2012

FIG. 14. Conventional station model plots $\left({ }^{\circ} \mathrm{F}\right)$ and subjective surface analyses from the NCEP Weather Prediction Center at (a) 1800 UTC 28 Feb, (b) 0000 UTC 29 Feb, (c) 0600 UTC 29 Feb, and (d) 1200 UTC 29 Feb 2012. Fronts are analyzed using standard symbols with the following notation: red: warm front, blue: cold front or Arctic front, purple: occluded front, and alternating red/blue: stationary front, dryline: light brown. Troughs are annotated as brown dashed lines. Isobars are drawn every $4 \mathrm{hPa}$ (solid brown contours).

determine the central pressure of these cyclones from 1973-78 to 1979-88, respectively. The mean central pressure of these cyclones was $1000 \mathrm{hPa}$, but ranged from 978 to $1020 \mathrm{hPa}$. The middle $50 \%$ were between 996 and $1006 \mathrm{hPa}$. Therefore, an intense cyclone is not required for mountain waves and severe downslope winds.

The intensity of the Christmas 2016 cyclone, and the strength of its circulation, may have been a factor in drawing the Arctic air into the system, facilitating 


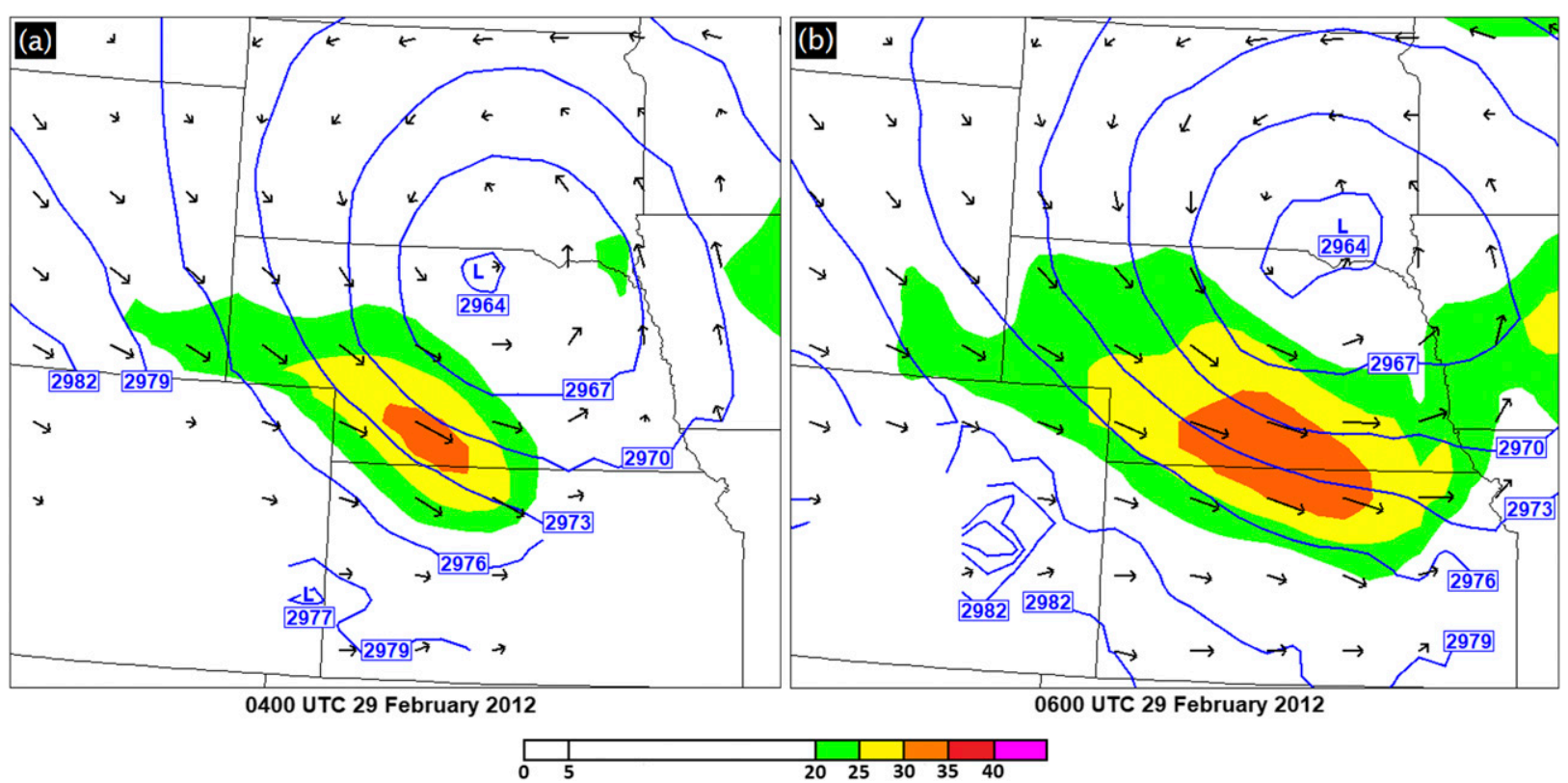

FIG. 15. RUC model forecast initialized at 0300 UTC 29 Feb 2012 for (a) 0400 and (b) 0600 UTC. Wind speed (shaded according to scale; $\mathrm{m} \mathrm{s}^{-1}$ ), wind vectors, and Montgomery streamfunction (blue contours in $100 \mathrm{~m}^{2} \mathrm{~s}^{-2}$ ) on the $290-\mathrm{K}$ potential temperature surface.

the eastward transport of the strongest winds. Deeper cyclones have a greater probability of occluding than weaker cyclones because their circulations are stronger (Schultz and Vaughan 2011). The Christmas 2016 cyclone was already occluded over eastern Colorado, whereas the cyclone on 28-29 February 2012 did not begin to occlude until it was over eastern Nebraska with a central pressure of around $990 \mathrm{hPa}$ (cf. Figs. 2 and 14). In this manner, the stronger cyclone on Christmas 2016 may have intensified the wind maximum, transported it farther eastward, and allowed more mixing downward than in the cyclone on 28-29 February 2012.

\section{Summary and implications for forecasting}

A surface mesoscale wind maximum occurred on 25-26 December 2016 in association with a strong cyclone crossing the central and northern plains. The result was a $130-\mathrm{km}$-wide swath of damaging surface winds that extended $850 \mathrm{~km}$ from Colorado to Minnesota. These winds were the result of a specific synoptic setup on that day, involving a deep extratropical cyclone in the lee of the Rockies, an elevated jet associated with mountain waves over Colorado and Wyoming, and an equatorward-moving Arctic front that provided a stable layer across which the elevated jet could be transported away from the mountains above the surface. This mesoscale wind maximum remained atop the Arctic air mass with its leading edge collocated with the front itself, with the two progressing downstream in tandem during which time the mesoscale wind maximum was increasingly supported by intense pressure gradients just south of the low center. The descent of the elevated wind maximum to the surface to yield the strong surface winds was facilitated by the neutral stability immediately behind Arctic front, allowing the descending air to more easily mix these strong winds to the surface. Although this wind maximum possessed many of the characteristics of a sting jet (e.g., descent within and evaporation of the comma cloud head of an extratropical cyclone), it was not a sting jet because the wind maximum was associated with mountain waves.

Other synoptic situations similar to the Christmas 2016 cyclone occur, but no swath of damaging surface winds develops. To understand why, a case was examined that occurred on 28-29 February 2012 where mountain waves and severe downslope winds occurred on the lee slopes of the Front Range and Laramie Mountains, but not until the cyclone was over southwest Minnesota. Although an Arctic front was northwest of the cyclone, just as with the Christmas 2016 cyclone, the front weakened considerably, leaving only stable lapse rates to the southwest of the cyclone. High winds still occurred above the stable polar air, associated with the cyclone itself, and eventually an elevated jet associated with mountain waves. However, due to the lack of a well-defined Arctic front, and the neutral lapse rates immediately behind it, the high winds remained above the stable polar air. 
The location of the Arctic air and the timing of the occurrence of mountain waves appear to be critical to two aspects of the winds with the Christmas 2016 storm. Without the layer of stable Arctic air farther west, the elevated jet associated with the mountain waves would not have been transported downstream away from the Front Range and Laramie Mountains. But without the well-mixed air immediately behind the Arctic front, the strong winds associated with the descending elevated jet may well have not reached the surface. As such, the Arctic air and a welldefined Arctic front are the key features for forecasters to recognize for predicting similar events in the future.

With an Arctic front and an unusually deep cyclone, there is a risk of a surface wind maximum associated with mountain waves whose leading edge moves far away from the mountains. If the Arctic front is not in place, or the mountain waves occur at a later time, the severe winds will remain limited to the lee slopes as normally occurs. Forecasters over the central and northern plains of the United States should be mindful of when mountain waves might occur, especially in the presence of a strong cyclone that could draw an Arctic front into its circulation. However, the predictability of mountain waves and downslope windstorms is limited due to initial condition uncertainty in numerical models, which can result in short lead times for forecasting these types of events. For example, Reinecke and Durran (2009) found that downslope wind speed forecasts can be quite sensitive to the initial conditions even an hour before the windstorms start, despite similar synoptic patterns. Despite that, forecasters well downstream of mountain ranges should be knowledgeable about the conditions that are favorable for mountain waves, and maintain vigilance in situations when mountain waves and downslope windstorms are possible.

Acknowledgments. We thank Roger Pielke Sr., Tsengdar Lee, Clark Payne, and Rob Cox for discussions while this work was being conducted. We appreciate the three anonymous reviewers whose input improved this article. We also thank Scott Bryant for his technical assistance in accessing archived data for this case, as well as Rick Ewald for reviewing an early version of the manuscript. We are also grateful to Marcy Meyer (Nebraska Department of Aeronautics), Dave Gorman (Federal Aviation Administration), Stonie Cooper (Nebraska Mesonet), and Bob Rilling (National Center of Atmospheric Research) for providing supplemental wind data. Partial funding for Schultz comes from the Natural Environment Research Council to the University of Manchester through Grants NE/I005234/1 and NE/I026545/1. Funding for Durran was provided by NSF Grant AGS-1545927.

\section{REFERENCES}

Ashley, W. S., and A. W. Black, 2008: Fatalities associated with nonconvective high-wind events in the United States. J. Appl. Meteor. Climatol., 47, 717-725, https://doi.org/ 10.1175/2007JAMC1689.1.

Baker, L., S. L. Gray, and P. A. Clark, 2014: Idealised simulations of sting-jet cyclones. Quart. J. Roy. Meteor. Soc., 140, 96-110, https://doi.org/10.1002/qj.2131.

Benjamin, S. G., A. Grell, J. M. Brown, T. G. Smirnova, and R. Bleck, 2004: Mesoscale weather prediction with the RUC hybrid isentropic/terrain-following coordinate model. Mon. Wea. Rev., 132, 495-518, https://doi.org/10.1175/1520-0493(2004) $132<0495$ :AHACTR $>2.0 . \mathrm{CO} ; 2$.

_ and Coauthors, 2016: A North American hourly assimilation and model forecast cycle: The Rapid Refresh. Mon. Wea. Rev., 144, 1669-1694, https://doi.org/10.1175/MWR-D-15-0242.1.

Bosart, L. F., W. E. Bracken, and A. Seimon, 1998: A study of cyclone mesoscale structure with emphasis on a large-amplitude inertiagravity wave. Mon. Wea. Rev., 126, 1497-1527, https://doi.org/ 10.1175/1520-0493(1998)126<1497:ASOCMS > 2.0.CO;2.

Brinkmann, W. A. R., 1974: Strong downslope winds at Boulder, Colorado. Mon. Wea. Rev., 102, 592-602, https://doi.org/10.1175/ 1520-0493(1974)102<0592:SDWABC $>2.0$.CO;2.

Browning, K. A., 2004: The sting at the end of the tail: Damaging winds associated with extratropical cyclones. Quart. J. Roy. Meteor. Soc., 130, 375-399, https://doi.org/10.1256/qj.02.143.

— , and M. Field, 2004: Evidence from Meteosat imagery of the interaction of sting jets with the boundary layer. Meteor. Appl., 11, 277-289, https://doi.org/10.1017/S1350482704001379.

— D. J. Smart, M. R. Clark, and A. J. Illingworth, 2015: The role of evaporating showers in the transfer of sting-jet momentum to the surface. Quart. J. Roy. Meteor. Soc., 141, 2956-2971, https://doi.org/10.1002/qj.2581.

Carlson, T. N., 1980: Airflow through midlatitude cyclones and the comma cloud pattern. Mon. Wea. Rev., 108, 1498-1509, https://doi.org/10.1175/1520-0493(1980)108<1498:ATMCAT> 2.0.CO;2.

_ 1998: Mid-Latitude Weather Systems. Amer. Meteor. Soc., 236 pp.

Chen, F., and J. Dudhia, 2001: Coupling an advanced land surfacehydrology model with the Penn State-NCAR MM5 modeling system. Part I: Model implementation and sensitivity. Mon. Wea. Rev., 129, 569-585, https://doi.org/10.1175/1520-0493(2001) $129<0569$ :CAALSH $>2.0 . \mathrm{CO} ; 2$.

Clark, P. A., and S. L. Gray, 2018: Sting jets in extratropical cyclones: A review. Quart. J. Roy. Meteor. Soc., 144, 943-969, https://doi.org/10.1002/qj.3267.

- K. A. Browning, and C. Wang, 2005: The sting at the end of the tail: Model diagnostics of fine-scale three-dimensional structure of the cloud head. Quart. J. Roy. Meteor. Soc., 131, 2263-2292, https://doi.org/10.1256/qj.04.36.

Compo, G. P., and Coauthors, 2011: The Twentieth Century Reanalysis Project. Quart. J. Roy. Meteor. Soc., 137, 1-28, https:// doi.org/10.1002/qj.776.

Cotton, W. R., J. F. Weaver, and B. A. Beitler, 1995: An unusual summertime downslope wind event in Fort Collins, Colorado, on 3 July 1993. Wea. Forecasting, 10, 786-797, https://doi.org/ 10.1175/1520-0434(1995)010<0786:AUSDWE > 2.0.CO;2.

Doyle, J. D., and D. R. Durran, 2002: The dynamics of mountainwave-induced rotors. J. Atmos. Sci., 59, 186-201, https://doi.org/ 10.1175/1520-0469(2002)059<0186:TDOMWI >2.0.CO;2.

Durran, D. R., 1986: Another look at downslope windstorms. Part I: The development of analogs to supercritical flow in 
an infinitely deep continuously stratified fluid. J. Atmos. Sci., 43, 2527-2543, https://doi.org/10.1175/1520-0469(1986) 043<2527:ALADWP>2.0.CO;2.

_ 1990: Mountain waves and downslope winds. Atmospheric Processes over Complex Terrain, W. Blumen, Ed., Amer. Meteor. Soc., 59-81.

Grønås, S., 1995: The seclusion intensification of the New Year's Day Storm 1992. Tellus, 47A, 733-746, https://doi.org/10.3402/ tellusa.v47i5.11571.

Iacono, M. J., J. S. Delamere, E. J. Mlawer, M. W. Shephard, S. A. Clough, and W. D. Collins, 2008: Radiative forcing by longlived greenhouse gases: Calculations with the AER radiative transfer models. J. Geophys. Res., 113, D13103, https://doi.org/ 10.1029/2008JD009944

Janjić, Z. I., 2002: Nonsingular implementation of the MellorYamada level 2.5 scheme in the NCEP Meso model. NCEP Office Note 437, $61 \mathrm{pp}$.

Knox, J. A., J. D. Frye, J. D. Durkee, and C. M. Fuhrmann, 2011: Nonconvective high winds associated with extratropical cyclones. Geogr. Compass, 5, 63-89, https://doi.org/10.1111/ j.1749-8198.2010.00395.x.

Lee, T. J., R. A. Pielke, R. C. Kessler, and J. Weaver, 1989: Influence of cold pools downstream of mountain barriers on downslope winds and flushing. Mon. Wea. Rev., 117, 2041-2058, https://doi.org/10.1175/1520-0493(1989) 117<2041:IOCPDO >2.0.CO;2.

Lilly, D. K., 1978: A severe downslope windstorm and aircraft turbulence event induced by a mountain wave. J. Atmos. Sci., 35, 59-77, https://doi.org/10.1175/1520-0469(1978) $035<0059$ :ASDWAA $>2.0 . \mathrm{CO} ; 2$.

Mellor, G. L., and T. Yamada, 1982: Development of a turbulence closure model for geophysical fluid problems. Rev. Geophys., 20, 851-875, https://doi.org/10.1029/RG020i004p00851.

Menchaca, M. Q., and D. R. Durran, 2017: Mountain waves, downslope winds, and low-level blocking forced by a midlatitude cyclone encountering an isolated ridge. J. Atmos. Sci. 74, 617-639, https://doi.org/10.1175/JAS-D-16-0092.1.

Mesinger, F., and Coauthors, 2006: North American Regional Reanalysis. Bull. Amer. Meteor. Soc., 87, 343-360, https://doi.org/ 10.1175/BAMS-87-3-343.

Miller, P. P., and D. R. Durran, 1991: On the sensitivity of downslope windstorms to the asymmetry of the mountain profile. J. Atmos. Sci., 48, 1457-1473, https://doi.org/10.1175/ 1520-0469(1991)048<1457:OTSODW >2.0.CO;2.

Morrison, H. G., G. Thompson, and V. Tatarskii, 2009: Impact of cloud microphysics on the development of trailing stratiform precipitation in a simulated squall line: Comparison of oneand two-moment schemes. Mon. Wea. Rev., 137, 991-1007, https://doi.org/10.1175/2008MWR2556.1.

NCEI, 2012: Storm Data. Vol. 54, https://www.ncdc.noaa.gov/IPS/ sd/sd.html.

— 2016: Storm Data. Vol. 58, https://www.ncdc.noaa.gov/IPS/sd/ sd.html.

Neiman, P. J., R. M. Hardesty, M. A. Shapiro, and R. E. Cupp, 1988: Doppler lidar observations of a downslope windstorm. Mon. Wea. Rev., 116, 2265-2275, https://doi.org/10.1175/ 1520-0493(1988)116<2265:DLOOAD > 2.0.CO;2.

NOAA/ESRL PSD, 2016: Boulder wind events. NOAA/ESRL, accessed 2 May 2017, https://www.esrl.noaa.gov/psd/boulder/ wind.html.

NWS, 2018: WFO non-precipitation weather products specification. National Weather Service Instruction 10-515, 6 pp. http:// www.nws.noaa.gov/directives/sym/pd01005015curr.pdf.
Parton, G., A. Dore, and G. Vaughan, 2010: A climatology of midtropospheric strong wind events as observed by the MST radar, Aberystwyth. Meteor. Appl., 17, 340-354, https://doi.org/ 10.1002/met.203.

Reinecke, P. A., and D. R. Durran, 2009: Initial-condition sensitivities and the predictability of downslope winds. J. Atmos. Sci., 66, 3401-3418, https://doi.org/10.1175/2009JAS3023.1.

Richard, E., P. Mascart, and E. C. Nickerson, 1989: The role of surface friction in downslope windstorms. J. Appl. Meteor., 28, 241-251, https://doi.org/10.1175/1520-0450(1989) $028<0241$ :TROSFI $>2.0 . \mathrm{CO} ; 2$.

Schneider, R. S., 1990: Large-amplitude mesoscale wave disturbances within the intense Midwest extratropical cyclone of 15 December 1987. Wea. Forecasting, 5, 533-558, https:// doi.org/10.1175/1520-0434(1990)005<0533:LAMWDW> 2.0.CO;2.

Schultz, D. M., 2001: Reexamining the cold conveyor belt. Mon. Wea. Rev., 129, 2205-2225, https://doi.org/10.1175/ 1520-0493(2001)129<2205:RTCCB > 2.0.CO;2.

- - , and G. Vaughan, 2011: Occluded fronts and the occlusion process: A fresh look at conventional wisdom. Bull. Amer. Meteor. Soc., 92, 443-466, https://doi.org/10.1175/ 2010BAMS3057.1.

, and J. M. Sienkiewicz, 2013: Using frontogenesis to identify sting jets in extratropical cyclones. Wea. Forecasting, 28, 603-613, https://doi.org/10.1175/WAF-D-12-00126.1.

, and K. A. Browning, 2017: What is a sting jet? Weather, 72, 63-66, https://doi.org/10.1002/wea.2795.

Schumacher, R. S., 2015: Resolution dependence of initiation and upscale growth of deep convection in convection-allowing forecasts of the 31 May-1 June 2013 Supercell and MCS. Mon. Wea. Rev., 143, 4331-4354, https://doi.org/10.1175/MWR-D-15-0179.1.

Shapiro, M. A., and D. Keyser, 1990: Fronts, jet streams and the tropopause. Extratropical Cyclones: The Erik Palmén Memorial Volume, C. W. Newton and E. O. Holopainen, Eds., Amer. Meteor. Soc., 167-191.

Skamarock, W. C., and Coauthors, 2008: A description of the Advanced Research WRF version 3. NCAR Tech. Note NCAR/ TN-475+STR, 113 pp., https://doi.org/10.5065/D68S4MVH.

Slater, T., D. M. Schultz, and G. Vaughan, 2015: Acceleration of near-surface strong winds in a dry, idealised extratropical cyclone. Quart. J. Roy. Meteor. Soc., 141, 1004-1016, https:// doi.org/10.1002/qj.2417.

$\longrightarrow,-$, and,- 2017 : Near-surface strong winds in a marine extratropical cyclone: Acceleration of the winds and the importance of surface fluxes. Quart. J. Roy. Meteor. Soc., 143, 321-332, https://doi.org/10.1002/qj.2924.

Smart, D. J., and K. A. Browning, 2014: Attribution of strong winds to a cold conveyor belt and sting jet. Quart. J. Roy. Meteor. Soc., 140, 595-610, https://doi.org/10.1002/qj.2162.

Stelten, S., and W. A. Gallus, 2017: Pristine nocturnal convective initiation: A climatology and preliminary examination of predictability. Wea. Forecasting, 32, 1613-1635, https://doi.org/10.1175/ WAF-D-16-0222.1.

Uccellini, L. W., and S. E. Koch, 1987: The synoptic setting and possible energy sources for mesoscale wave disturbances. Mon. Wea. Rev., 115, 721-729, https://doi.org/10.1175/1520-0493(1987) 115<0721:TSSAPE $>2.0 . \mathrm{CO} ; 2$.

Zishka, K. M., and P. J. Smith, 1980: The climatology of cyclones and anticyclones over North America and surrounding environs for January and July, 1950-77. Mon. Wea. Rev., 108, 387-401, https://doi.org/10.1175/15200493(1980)108<0387:TCOCAA > 2.0.CO;2. 